\title{
Prospects for Durable Resistance Against an Old Soybean Enemy: A Four-Decade Journey from Rpp1 (Resistance to Phakopsora pachyrhizi) to Rpp7
}

\author{
Subhash Chander ${ }^{1,2} \oplus$, Alejandro Ortega-Beltran ${ }^{1} \oplus$, Ranajit Bandyopadhyay ${ }^{1} \oplus$, \\ Parvender Sheoran ${ }^{3}$, Gbemisola Oluwayemisi Ige ${ }^{1,4}$, Marta W. Vasconcelos ${ }^{5}$ (i) and \\ Ana Luisa Garcia-Oliveira ${ }^{1, *(1)}$ \\ 1 International Institute of Tropical Agriculture, PMB 5320, Ibadan 200001, Nigeria \\ 2 Department of Genetics \& Plant Breeding, Chaudhary Charan Singh Haryana Agricultural University, \\ Hisar 125004, Haryana, India \\ 3 ICAR-Central Soil Salinity Research Institute, Karnal 132001, Haryana, India \\ 4 Life and Earth Sciences Institute, Pan African University, PMB 20, Ibadan 200001, Nigeria \\ 5 Universidade Católica Portuguesa, CBQF-Centro de Biotecnologia e Química Fina-Laboratório Associado, \\ Escola Superior de Biotecnologia, Rua Diogo Botelho 1327, 4169-005 Porto, Portugal \\ * Correspondence: a.oliveira@cgiar.org; Tel.: +234-700800 (ext. 2111)
}

Received: 4 May 2019; Accepted: 26 June 2019; Published: 1 July 2019

\begin{abstract}
Soybean rust (SBR), caused by Phakopsora spp., is a major global concern for soybean producers. SBR causing fungi are polycyclic and obligate biotrophs, rendering the study of their biology particularly tedious. Over the past four decades, substantial progress has been made towards understanding the epidemiology of the disease, the identification of sources of resistance, and the mapping of soybean loci conferring resistance to P. pachyrhizi (Rpp genes), since this species is particularly well established and widespread in many soybean growing areas. Although host-plant resistance is generally considered as the most desirable solution from an environmental, economic, and social perspective, other disease control approaches such as agronomic practices and chemical application are also important, and influence rust epidemiology as well as the durability of host plant resistance. This review focusses primarily on genetic aspects of SBR management and summarizes the research in the following areas: SBR symptoms, aetiology, pathogenic variation and population structure of Phakopsora populations, expression of soybean resistance to Phakopsora infection, genetics and molecular diagnostics of host resistance to pathogen, and resistance gene deployment approaches. Finally, the role of multidisciplinary strategies is discussed for achieving higher durability of SBR resistance in soybean.
\end{abstract}

Keywords: Asian soybean rust; soybean rust; long-lasting resistance; molecular diagnostics; P. pachyrhizi

\section{Introduction}

Soybean is the most important leguminous oilseed crop worldwide, with seeds containing high amounts of both protein (about $40 \%$ ) and oil (about $20 \%$ ). Thus, soybean is also called a "two-in-one crop". The origin of soybean domestication is thought to be in China [1], but its great adaptability to different latitudes, climatic and soil conditions enabled soybean to become the fourth most widely grown crop across the globe after wheat, maize and rice (http://faostat.fao.org/). More than 300 species of pathogens attack soybean worldwide, although relatively few cause significant economic damage [2]. In 2003, the estimated worldwide loss due to biotic stresses in soybean was $23 \%$ of which $11 \%$ were due to plant pathogenic bacteria and fungi, $1 \%$ were due to viruses and $11 \%$ were due to pests, including insects and nematodes [3]. 
Generally, biotic stresses tend to be geographically and environmentally restricted [4]. However, soybean rust, particularly Asian soybean rust, is interestingly unique. It is considered to originate in Asia-Australia, but subsequently spread to most soybean-producing areas across very different climatic conditions including tropical, subtropical, and temperate climates on different continents [2,5-7]. The yield loss due to soybean rust may vary but it has the potential to cause more than $80 \%$ yield loss in susceptible cultivars under favourable conditions [8-10]. Therefore, the challenges are enormous since no geographic region is free from the occurrence of soybean rust.

In order to minimize disease severity, numerous crop management practices such as early planting, wider spacing between rows or planting of early maturing cultivars have been advocated. However, the efficacy of such practices is highly dependent on the environmental conditions [11,12]. Chemical control is considered as one of the most effective methods for managing soybean rust worldwide. The application of fungicides adds significantly to production costs particularly if more number of applications are needed during the growing season. Furthermore, the overuse of chemicals may not only pose environmental challenges but frequent pathogen exposure to a fungicide may result in development of resistance [13]. Therefore, deployment of resistant cultivars not only seems to be the most sustainable approach to manage soybean rust from broader perspectives, but also could be a most economically viable option in subsistence production systems in developing countries especially in Africa.

\section{Soybean Rust: Causal Pathogen}

Rust fungi are obligate pathogens and thus can only grow on living plants. Some of the rust fungi complete their life cycle with five different spore stages: spermatia, aeciospores, urediniospores, teliospores, and basidiospores [14]. All those types of spores are highly specialized for infection of specific hosts [7]. Rust fungi requiring the five spore stages to complete their life cycle are termed macrocyclic. However, for some rust fungi such as soybean rust, the complete life cycle has not been described $[7,15]$. For instance, only urediniospores and teliospores of soybean rust have been observed in nature. However, germination of teliospores has not observed in nature and thus the sexual cycle of soybean rust has not been elucidated [16].

The causal agent of soybean rust was first described in Japan in 1902 on yam bean (Pachyrhizus ahipa) [17]. However, an isolate from the leguminous host crop Pachyrhizus erosus (L.) Urb. (= Pachyrhizus angulatus) in Taiwan, is the source of the fungus's current name, Phakopsora pachyrhizi Syd. \& P. Syd. [18].

In 1976, Vakili and Bromfield [19] reported that Puerto Rican isolates of Phakopsora were considerably less virulent and produced fewer urediniospores on soybean than isolates from the Eastern Hemisphere. At the time, they believed that P. pachyrhizi was also the causal agent of the disease in Puerto Rico. In 1988, Bonde and co-workers [20] compared one isolate from Puerto Rico, three from Brazil and 11 isolates from widely separated areas of Asia and Australia using isozyme analysis, and suggested that there were two different species of Phakopsora causing rust on soybean: one in Asia and the Eastern Hemisphere, and one in the "New World" (South and Central America and the Caribbean) [20].

Subsequently, a comprehensive paper on the morphology of the Phakopsora species on legumes in 1992 further confirmed the relationships of rust pathogens on legumes, in which it was clarified that soybean rust is caused by at least two species [21]. Phakopsora pachyrhizi was determined as the causal agent of soybean rust in Asia, while in the "New World", P. meibomiae (Arthur) Arthur, known to be present on non-soybean legumes since 1899, was referred as the causing agent [21]. These species have posteriorly been differentiated at DNA level. The analysis of the internal transcribed spacer (ITS) region of the ribosomal RNA genes revealed that $P$. pachyrhizi and P. meibomiae share approximately $80 \%$ nucleotide sequence similarity [22].

\section{Symptoms, Disease Development and Host Range}

Phakopsora spp. can infect all the aerial parts of the soybean plant such as stem, pod and petiole but the pathogen prefers leaves (Figure 1). The most common symptoms are tan to dark-brown or 
reddish-brown lesions with one to many erumpent, globose uredinia, particularly on the abaxial surface of leaflets [2]. Lesions tend to be angular and restricted by leaf veins and are frequently associated with leaf chlorosis. Under heavy infection, this may result in premature defoliation and early maturity, or failure to even reach maturity.

A

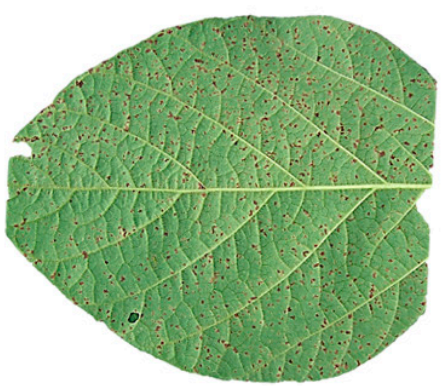

B

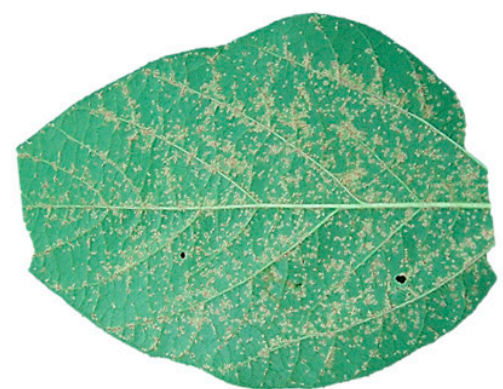

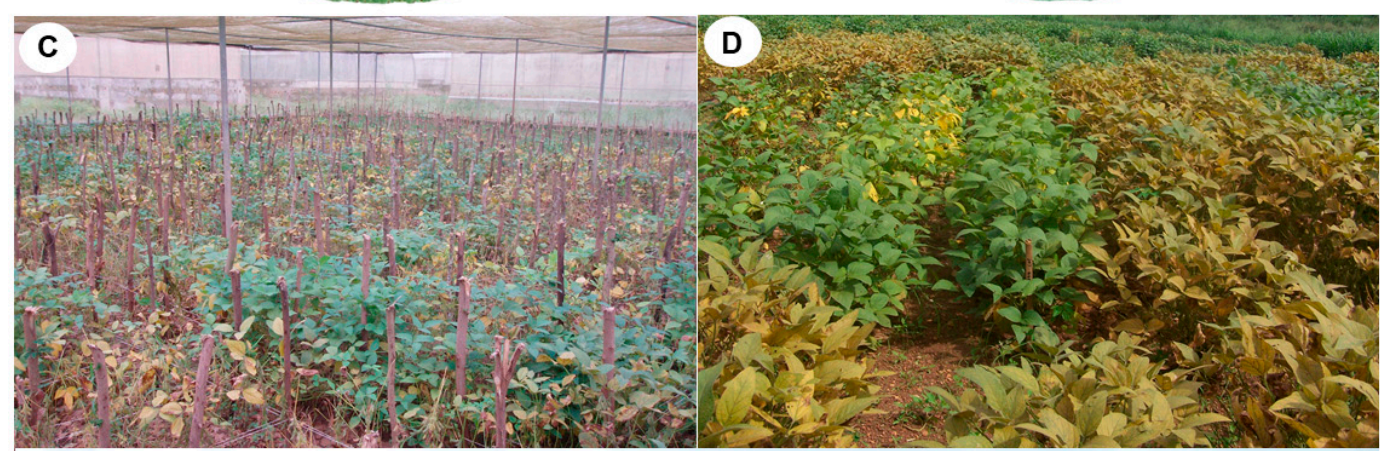

E

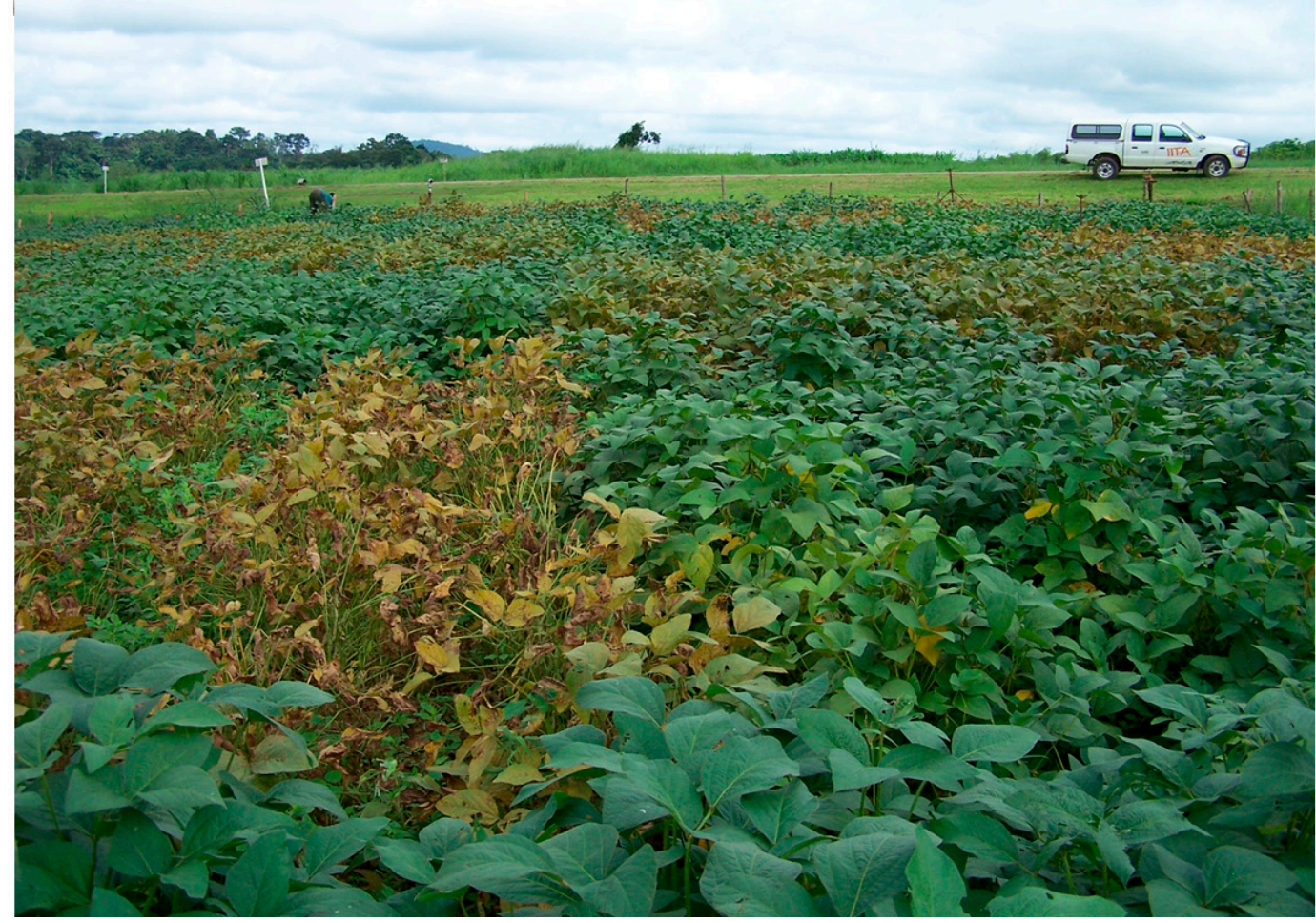

Figure 1. Soybean rust (Phakopsora pachyrhizi) symptoms on infected leaves and on whole plants in screenhouse and field conditions at IITA, Nigeria. (A,B) P. pachyrhizi reaction on the lower surface of a soybean rust-resistant and susceptible soybean leaf, respectively; (C,D) Reaction of adult plants to P. pachyrhizi under screenhouse and field conditions, respectively; (E) Premature death and defoliation in heavily soybean rust infected soybean lines. [Source of Photos: Ranajit Bandyopadhyay]. Note: soybean rust symptoms might slightly vary across locations. 
For disease development, the majority of rust fungi enter the host leaf tissues via stomata at the uredinial stage, but Phakopsora spp. directly penetrate the leaf epidermal cells [9]. Phakopsora fungi can attack the soybean plant at any stage, depending on environmental conditions. A prolonged wet and cool period (daily temperature $<28{ }^{\circ} \mathrm{C}$ ) strongly favours infection and sporulation. Windborne urediniospores, the primary means of disease spread, require free water for germination and penetration, and can complete the cycle from initial infection to urediniospore production in as little as nine days [9].

Several Fabaceae plants are the most common alternative hosts of soybean rust. For instance, kudzu [Pueraria lobata (Willd) Ohwi.] has been observed as alternative host in Japan and southern USA, and acts as a green bridge between soybean crops across seasons. Until now, approximately 160 host species in 53 genera have been reported as alternative hosts in the absence of the soybean crop $[4,7]$. However, the host range is continuously increasing as the footprints of the Phakopsora spp. expand beyond the traditional areas of soybean production.

\section{Soybean Rust: Geographical Footprints}

Presently, it is well established that soybean rust (SBR) is caused by two obligate biotrophic fungal species: P. pachyrhizi (anamorph Malupa sojae; Asian-Australian) and P. meibomiae (anamorph Malupa vignae; Latin American). Phakopsora pachyrhizi is more aggressive and within few decades of the first report of P. pachyrhizi in Japan in 1903, the pathogen was discovered throughout Asia and as far south as Australia. The SBR caused by these Asian-Australian isolates of P. pachyrhizi is widely referred as Asian soybean rust in literature. In the second half of the 20th century, the footprint of P. pachyrhizi appeared to be moving into several soybean growing countries in Africa, suggesting a wider range of adaptation [23,24]. Similarly, the detection of P. pachyrhizi on soybean grown in Hawaii in 1994, suggested that the disease could become an economic threat in soybean production in the Americas, since it was believed that the American continents were free of P. pachyrhizi. Within a decade of the first report of P. pachyrhizi in Hawaii, the pathogen appeared in Paraguay and became established in major soybean growing countries in South America, particularly Bolivia, Brazil and Argentina [25,26]. Later on, the disease was reported in the USA in $2004[27,28]$.

On the other hand, P. meibomiae, another causal agent of SBR, is less aggressive [21,29]. Even though the outbreak of SBR reported in Puerto Rico [19] and subsequently observed in Brazil, Colombia and Costa Rica [16] was caused by P. meibomiae [29], the pathogen is still considered as minor, since its footprint did not expand beyond the Central and South America and the Caribbean regions.

\section{Pathogenic Variation and Population Structure of Phakopsora Fungi}

Over a century ago, Barrus [30] demonstrated that physiologic specialization (races) existed in the case of several pathogens. Since then, the identification of pathogenic races in populations of different plant pathogens has continued. Our understanding on components of pathogenic variation has improved over the period but overlapping usage of some terms often confused the readers. For instance, the term aggressiveness is sometimes used instead of virulence. In any doubt, the readers may consult past reviews where these terms explicitly described elsewhere [31-33]

The diversity in the virulence of a pathogen demands finding superior genetic resources to breed resistant cultivars with broad and durable resistance against a range of pathogen genotypes in a specific region [34]. The earliest report on pathogenic variation in Phakopsora fungus goes back to Taiwan where Lin [35] demonstrated that $P$. pachyrhizi isolates collected from soybean varied in their pathogenicity and virulence on several other leguminous hosts. Subsequently, two pathotypes of P. pachyrhizi were reported in Australia [36], with one being virulent on line PI 200492, previously classified as immune. PI 200492 was subsequently confirmed as the source of the first soybean resistance gene to P. pachyrhizi (Rpp1) [37].

In order to understand pathogenic variation, it is necessary to understand the pathogen's life cycle. For P. pachyrhizi, there have been no reports of sexual reproduction. Teliospores have been observed in Asian nations on several hosts, including soybean, but their germination has never been 
reported in nature [16]. Despite the unknown or missing sexual life cycle of P. pachyrhizi, high genetic diversity exists within and among field populations, and is likely to continue to evolve. This may occur through asexual mechanisms such as genome plasticity and compartmentalization, parasexuality, or somatic hybridization resulting from hyphal anastomosis between isolates from distinct clonal origin, a feature also reported for cereal rusts [38-41]. At 5-8 days post inoculation, $P$. pachyrhizi produces asexual urediospores on short stalks within a uredium on colonized leaves. The urediniospores are released from uredia through an ostiole and become scattered by the wind [7].

Initial studies evaluating pathogenicity had some challenges. The soybean differentials used in the studies conducted prior to the 1980s were genetically undefined, as there was no information on which resistance genes were present in the evaluated cultivars. With advances in knowledge of the genetics of SBR resistance, cultivars with identified single resistance genes were used as differentials. This led to the identification of several pathotypes of Phakopsora spp. in major soybean producing countries (Table 1). However, the experiments conducted in different countries during the past two decades suggest that there is much more diversity in field populations of P. pachyrhizi than what was thought during the last quarter of the 20th century. The size of differential sets used in earlier studies was often small (Table 2).

More recent studies use several genetically well-defined differentials containing different $R p p$ genes, together with molecular makers that provide rapid and accurate identification of P. pachyrhizi and P. meibomiae strains. For instance, Yamaoka et al., [42] classified 45 single uredinial isolates of P. pachyrhizi collected from rust-infected soybean and wild host plants, kudzu and wild soybean (Glycine soja Siebold \& Zucc.) in central and southwestern Japan into 18 races on the basis of rust reaction patterns in a set of 11 differentials containing the resistance genes Rpp1, Rpp2, Rpp3, and Rpp4. Among these 18 races, two were common to soybean and wild host plants while seven and nine races were found exclusively on soybean and wild host plants, respectively. Most of the races associated with soybean possessed a virulence gene for Rpp1. Posteriorly, Yamaoka et al., [43] also reported six races among 26 single lesion isolates of $P$. pachyrhizi from Japan, and indicated that two or more races may be distributed on the same soybean cultivar and that the same race shares soybean and kudzu hosts.

Akamatsu et al., [44] evaluated 59 P. pachyrhizi populations from South America comprising of 16 from Argentina, 24 from Brazil, and 19 from Paraguay. These isolates were evaluated in their pathogenicity to 16 soybean differentials including the ones containing known resistance loci (Rpp1, Rpp2, Rpp3, Rpp4 and Rpp5). The Rpp1 in PI 587880A and Rpp5 were found to be effective mainly against recent pathogen populations, because the differentials containing resistance genes Rpp1, Rpp2, Rpp3 and Rpp4, except for PI 587880A which also contains Rpp1, displayed resistance to only 1.8-14, 24-28, 22 and 36\% of the South American P. pachyrhizi populations, respectively. More recently, the pathogenic profiles of four $P$. pachyrhizi populations from northeastern Mexico against 12 soybean differentials revealed that P. pachyrhizi population MRP-14 was highly virulent on the resistant soybean differentials [45]. Moreover, the results also indicated that P. pachyrhizi populations from Mexico have higher virulence than populations from south America and Japan.

In Nigeria, 116 P. pachyrhizi isolates collected from diverse agro-ecological zones were grouped into seven clusters displaying considerable differences in the pathotype composition based upon the reactions of eight differentials, some of which had the Rpp1 to Rpp4 resistance genes [46]. Similarly, Murithi et al., [47] also studied pathogenic diversity of P. pachyrhizi populations in eastern Africa using 12 isolates from Tanzania, three isolates from Malawi and one isolate each from Kenya and South Africa using 11 differential varieties and compared to a geographically diverse collection. Among the African isolates, the isolate from South Africa (SA-14-01) was the most virulent, whereas those from Kenya, Malawi, and some of the isolates from Tanzania had the lowest virulence. Soybean differentials carrying Rpp1b, Rpp2, Rpp3, and Rpp5a and cultivars Hyuuga (Rpp3 and Rpp5) and UG5 (Rpp1 and $R p p 3$ ) were observed to be resistant against most of the African isolates [47]. 
Table 1. Phenotypic reactions of global soybean rust isolates to different $R p p$ genes soybean differential hosts.

\begin{tabular}{|c|c|c|c|c|c|c|c|c|c|c|}
\hline \multirow{2}{*}{$\begin{array}{l}\text { Phakopsora } \\
\text { Species }\end{array}$} & \multirow{2}{*}{ Country } & \multirow{2}{*}{ Pathotype/Isolate } & \multicolumn{7}{|c|}{ Soybean Differential Hosts with Rust Resistant Genes/Loci (Resistance to Phakopsora pachyrhizi) } & \multirow{2}{*}{ References } \\
\hline & & & Rpp1 & Rpp2 & Rpp3 & Rpp4 & Rpp5 & Rpp6 & Rpp7 & \\
\hline \multirow{36}{*}{ P. pachyrhizi } & Banoladoch & BdRP-1 & & & & & & & & \\
\hline & Dangracesn & BdRP-2,5,8,11,12,14,22 & & & & & & & & \\
\hline & & BdRP-3 & & & & & & & & \\
\hline & & BdRP-7 & & & & & & & & [48] \\
\hline & & BdRP-9 & & & & & & & & \\
\hline & & BdRP-17 & & & & & & & & \\
\hline & & BdRP-18 & & & & & & & & \\
\hline & India & IN 73-1 & & & & & & & & {$[29,49-57]$} \\
\hline & Japan & JRP & & & & & & & & {$[58]$} \\
\hline & Philippines & PH 77-1 & & & & & & & & {$[25,43]$} \\
\hline & Taiwan & TW 72-1 & & & & & & & & \\
\hline & & TW 80-1 & & & & & & & & {$[29,49-54$,} \\
\hline & & TW 80-2 & & & & & & & & \\
\hline & Thailand & TH 01-1 & & & & & & & & [29] \\
\hline & Vietnam & VT 05-1 & & & & & & & & {$[53,54,57]$} \\
\hline & & AU 72-1 & & & & & & & & {$[29,49,51$,} \\
\hline & Australia & AU 79-1 & & & & & & & & $52,57]$ \\
\hline & Argentina & $\begin{array}{c}\text { ARG-14-01 } \\
\text { ARG-14-02 to -04 }\end{array}$ & & & & & & & & [47] \\
\hline & Brazil & BZ $01-1$ & & & & & & & & \\
\hline & & BRP-1 & & & & & & & & {$[29,51,58$,} \\
\hline & & BRP-2 & & & & & & & & \\
\hline & Columbia & CO 04-2 & & & & & & & & {$[53,54,57]$} \\
\hline & Paraguay & PG 01-2/PG 01-2b & & & & & & & & {$[29,51]$} \\
\hline & Mexico & MRP-4 & & & & & & & & {$[45]$} \\
\hline & & MRP-13 & & & & & & & & \\
\hline & & MRP-16 & & & & & & & & \\
\hline & & MRP-19 & & & & & & & & \\
\hline & USA & AL 04-1 & & & & & & & & \\
\hline & & AL 04-3 & & & & & & & & {$[29,51-54$,} \\
\hline & & LA 04-1 & & & & & & & & \\
\hline & & LA 04-3 & & & & & & & & \\
\hline & & GA 12-1 & & & & & & & & \\
\hline & & HW 98-1 & & & & & & & & \\
\hline & & HW 94-1 & & & & & & & & \\
\hline & South & SA 01-1 & & & & & & & & {$[29,47,51$,} \\
\hline & Africa & SA-14-1 & & & & & & & & 53-55] \\
\hline
\end{tabular}


Table 1. Cont.

\begin{tabular}{|c|c|c|c|c|c|c|c|c|c|c|}
\hline \multirow{2}{*}{$\begin{array}{l}\text { Phakopsora } \\
\text { Species }\end{array}$} & \multirow{2}{*}{ Country } & \multirow{2}{*}{ Pathotype/Isolate } & \multicolumn{7}{|c|}{ Soybean Differential Hosts with Rust Resistant Genes/Loci (Resistance to Phakopsora pachyrhizi) } & \multirow{2}{*}{ References } \\
\hline & & & Rpp1 & Rpp2 & Rpp3 & Rpp4 & Rpp5 & Rpp6 & Rpp 7 & \\
\hline & South & SA 01-1 & & & & & & & & {$[29,47,51$,} \\
\hline & Africa & SA-14-1 & & & & & & & & 53-55] \\
\hline & Zimbabwe & ZM 01-1 & & & & & & & & $\begin{array}{c}{[29,52-55,} \\
571\end{array}$ \\
\hline & Nigeria & NIG-05-06 & & & & & & & & [45] \\
\hline & Kenya & KE-12-01 & & & & & & & & [47] \\
\hline & Malawi & MAL-14-01,-2 & & & & & & & & [47] \\
\hline & & MAL-14-03 & & & & & & & & \\
\hline & Tanzania & TZ-14-01 to -06 & & & & & & & & [47] \\
\hline & & TZ-14-07 & & & & & & & & \\
\hline & & TZ-14-08 & & & & & & & & \\
\hline & & TZ-14-09 to -12 & & & & & & & & \\
\hline \multirow{2}{*}{ P. meibomiae } & Brazil & BZ 82-1 & & & & & & & & \multirow{2}{*}{ [29] } \\
\hline & Puerto & PR 76 & & & & & & & & \\
\hline
\end{tabular}


Table 2. Description of Rpp genes, genomic positions, nearest molecular markers and their original as well as other sources in soybean germplasm.

\begin{tabular}{|c|c|c|c|c|c|c|c|c|c|}
\hline $\begin{array}{l}\text { Gene } \\
\text { Locus }\end{array}$ & Chr. & Physical Position & $\begin{array}{l}\text { Nearest } \\
\text { Molecular } \\
\text { Markers }\end{array}$ & $\begin{array}{l}\text { Original } \\
\text { Genotype } \\
\text { [Accession } \\
\text { (cultivar)] }\end{array}$ & $\begin{array}{l}\text { Source of } \\
\text { Origin }\end{array}$ & $\begin{array}{c}\text { Description of Mapping } \\
\text { Population }\end{array}$ & $\begin{array}{l}\text { P. pachyrhizi } \\
\text { Isolate and Its } \\
\text { Reaction to } \\
\text { Resistant Parent }\end{array}$ & $\begin{array}{c}\text { Soybean Sources other } \\
\text { than Original Genotype } \\
\text { with Similar Resistant } \\
\text { Gene/Locus }{ }^{\ddagger}\end{array}$ & References \\
\hline Rpp1 & $\begin{array}{l}18 \\
(G)\end{array}$ & $56,182,523-56,797,174$ & $\begin{array}{l}\text { Sct_187, } \\
\text { Satt191, } \\
\text { Sat_064 }\end{array}$ & $\begin{array}{l}\text { PI } 200492 \\
\text { (Komata) }\end{array}$ & $\begin{array}{l}\text { Shikoku, } \\
\text { Japan }\end{array}$ & $\begin{array}{c}126 \mathrm{BC}_{6} \mathrm{~F}_{2} \text { lines derived } \\
\text { from Williams } 82^{\prime} \text { x PI } \\
200492\end{array}$ & IR against IN73-1 & $\begin{array}{l}\text { PI 594538A, PI 587886, PI } \\
\text { 587880A, PI 594760B, PI } \\
\text { 561356, PI 594767A, PI } \\
\text { 587905, PI 594177, PI } \\
\text { 587855, EC 241780, } \\
\text { UG-5*, Xiao Jing Huang } \\
\text { and Himeshirazu }\end{array}$ & $\begin{array}{c}{[37,52,55,} \\
61-69]\end{array}$ \\
\hline$R p p 2$ & $\begin{array}{l}16 \\
(J)\end{array}$ & $27,937,049-30,478,472$ & $\begin{array}{c}\text { Satt183, } \\
\text { Sat_255, } \\
\text { Satt620, Sct_01 }\end{array}$ & PI 230970 & Japan & $\begin{array}{c}130 \mathrm{~F}_{2: 3} \text { families derived } \\
\text { from BRS } 184^{\prime} \times \text { PI } \\
230970\end{array}$ & $\begin{array}{l}\text { RB against isolate } \\
\text { (mixture) } \\
\text { maintained on } \\
\text { BRSMS Bacuri } \\
\text { cultivar }\end{array}$ & $\begin{array}{l}\text { PI 230970, PI 224270, PI } \\
\text { 417125, An-76*, EC } \\
\text { 241780* and Iyodaizu B }\end{array}$ & $\begin{array}{l}{[49,50,66} \\
67,70-74]\end{array}$ \\
\hline Rpp3 & $\begin{array}{c}6 \\
(\mathrm{C} 2)\end{array}$ & $44,049,891-45,995,029$ & $\begin{array}{l}\text { Satt658, } \\
\text { Sat_263, } \\
\text { Satt460, } \\
\text { Satt307 }\end{array}$ & $\begin{array}{l}\text { PI } 462312 \\
\text { (Ankur) }\end{array}$ & $\begin{array}{l}\text { Pant Nagar, } \\
\text { India }\end{array}$ & $\begin{array}{c}110 \mathrm{~F}_{2: 3} \text { families derived } \\
\text { from Williams } 82^{\prime} \times \mathrm{PI} \\
462312\end{array}$ & RB against IN73-1 & $\begin{array}{c}\text { PI 462312, UG-5*, PI } \\
\text { 506764*, PI 628932, PI } \\
\text { 567099A, PI 416764, PI } \\
\text { 635999* }\end{array}$ & $\begin{array}{l}{[50,51,53} \\
65,75-78]\end{array}$ \\
\hline Rpp4 & $\begin{array}{l}18 \\
(G)\end{array}$ & $51,397,064-51,584,617$ & $\begin{array}{l}\text { Satt288, } \\
\text { Satt612, } \\
\text { AF162283, }\end{array}$ & $\begin{array}{l}\text { PI 459025B } \\
\text { (Bing nan) }\end{array}$ & Fujian, China & $\begin{array}{c}80 \mathrm{~F}_{2: 3} \text { families derived } \\
\text { from BRS } 184^{\prime} \times \mathrm{PI} \\
459025\end{array}$ & $\begin{array}{l}\text { RB against isolate } \\
\text { (mixture) } \\
\text { maintained on } \\
\text { BRSMS Bacuri } \\
\text { cultivar }\end{array}$ & $\begin{array}{l}\text { PI 459025B, PI 423972, } \\
\text { An-76*, PI 635999* }\end{array}$ & $\begin{array}{l}{[56,71-73,} \\
78-81]\end{array}$ \\
\hline rpp5 & $\begin{array}{l}3 \\
(\mathrm{~N})\end{array}$ & $29,862,641-32,670,690$ & $\begin{array}{l}\text { Sat_166, } \\
\text { Sat_275, } \\
\text { Sat_280 }\end{array}$ & $\begin{array}{l}\text { PI } 200456 \\
\text { (Awashima } \\
\text { Zairai) }\end{array}$ & $\begin{array}{l}\text { Shikoku, } \\
\text { Japan }\end{array}$ & $\begin{array}{c}173,174 \& 177 \mathrm{~F}_{2} \\
\text { individuals from cross of } \\
\text { CD 208 with resistant } \\
\text { lines PI 200456, PI } 471904 \\
\text { \& PI 200526, respectively. }\end{array}$ & $\begin{array}{l}\text { RB against isolate } \\
\text { (mixture) } \\
\text { maintained on } \\
\text { BRSMS Bacuri } \\
\text { cultivar }\end{array}$ & $\begin{array}{l}\text { PI 200526, PI 200526, PI } \\
\text { 200487, PI 471904, PI } \\
\text { 506764* , Kinoshita }\end{array}$ & $\begin{array}{l}{[53,70,71} \\
\quad 73]\end{array}$ \\
\hline Rpp6 & $\begin{array}{l}18 \\
(\mathrm{G})\end{array}$ & $5,953,237-6,898,528$ & $\begin{array}{l}\text { Satt324, } \\
\text { Satt394 }\end{array}$ & PI 567102B & $\begin{array}{l}\text { East Java, } \\
\text { Indonesia }\end{array}$ & $\begin{array}{c}273 \mathrm{~F}_{2} \text { and } 104 \mathrm{~F}_{2: 3} \\
\text { families derived from } \\
\text { DS-880 } \times \text { PI } 567102 \mathrm{~B}\end{array}$ & $\begin{array}{l}\text { IR to RB against } \\
\text { MS06-1 and RB } \\
\text { against LA04-1 }\end{array}$ & $\begin{array}{c}\text { PI 567102B, PI 567068A, } \\
\text { PI 567104B }\end{array}$ & {$[60,82,83]$} \\
\hline Rpp7 & $\begin{array}{l}19 \\
(\mathrm{~L})\end{array}$ & $39,462,291-39,616,643$ & $\begin{array}{l}\text { GSM0547, } \\
\text { GSM0548 }\end{array}$ & $\begin{array}{c}\text { PI } 605823 \\
\text { (SAMPLE 87) }\end{array}$ & $\begin{array}{l}\text { Ha Giang, } \\
\text { Vietnam }\end{array}$ & $\begin{array}{c}87 \mathrm{~F}_{2: 3} \text { families derived } \\
\text { from Williams } 82 \text { ' } \times \text { PI } \\
605823 \& 84 \mathrm{~F}_{4: 5} \text { RILs } \\
\text { from ‘ } 5601 \mathrm{~T}^{\prime} \times \text { PI } 605823\end{array}$ & RB against GA12 & - & [57] \\
\hline
\end{tabular}

$\ddagger$ Genotype may contain same or different allele at respective gene/locus than that was identified in original source; ${ }^{*}$ Genotype contain multiple resistant Rpp loci/genes. 
Contrary to what is known about wheat rusts and other small grains rusts, information on P. pachyrhizi population structure at national and international level is very limited $[84,85]$. The advent of DNA-based technologies not only opened new avenues for the assessment of genetic diversity in rust populations, but molecular markers can be used for strain detection and identification. Freire et al., [26] investigated the genealogical relationships among Brazilian, African, and Asian P. pachyrhizi isolates using ITS sequence variation and observed that ribotypes with the most widespread occurrence in Brazil were more closely related to isolates from Africa than from Asia. On the other hand, ribotypes of rare occurrence in Brazil were not found in collections from outside of Brazil and were limited to a single field or to fields in the same vicinity. Using simple sequence repeat (SSR) markers, Twizeyimana et al., [86] identified 84 distinct genotypes in the sampled populations of P. pachyrhizi that exhibited a high degree of genetic variation. The examined isolates were grouped into seven pathotypes based on the virulence on differential soybean genotypes. Similarly, based on sequence variation of ITS and the ADP-Ribosylation Factor (ARF) gene obtained from 59 P. pachyrhizi isolates collected from different soybean producing countries including USA, at least five genotypes were identified within USA isolates [87].

In general, data from both differential genotypes and molecular marker studies show that most of the genetic variation in P. pachyrhizi that existed among locations was also found within location even when considering at large geographic areas [26,86-88]. The weak genetic structure and differentiation in P. pachyrhizi on a larger geographic scale suggests that both local and distant sources of airborne inoculum are important for the re-establishment, as well as the maintenance of minimum levels of fluctuation in the genetic composition of P. pachyrhizi populations from year to year [89]. Indeed, atmospheric pathways are thought to have contributed to the establishment of the pathogen in the USA, with airborne spores transported by hurricanes with an epicenter in South America [6]. Similar events may have introduced the pathogen in other countries.

\section{Expression of Host Resistance to Phakopsora Infection}

The appearance of lesions and their colour are often used to determine soybean susceptibility or resistance to SBR. Broadly, three general infection types have been described: (1) susceptible reaction, characterized by tan-coloured "TAN" lesions, at least partly due to the abundance of beige-coloured uredinospores and abundant sporulation on the abaxial sides of infected leaves; (2) resistant reaction typified by reddish-brown-coloured "RB" lesions with few uredinia and meagre sporulation; and (3) immune reaction (IR) distinguished by a lack of macroscopically visible lesions or uredinia $[16,49]$.

The presence of continuous variation in lesion colour among soybean cultivars makes it difficult to classify the reactions of soybean phenotypes to some isolates into a limited number of lesion types, such as RB and TAN lesions [16]. Notably, rust resistance genes such as Rpp2 and Rpp4 are known to contribute to the darkness of lesion colour [90]. Nonetheless, lesion colour should be considered for rapid screening of breeding populations especially when selecting resistant genotypes but needs to be more conscious because the presence of continuous variation in the trait and substantial environmental influence makes colour unlikely to be a sole criterion for resistance classification of genotypes [58,91].

Yamanaka et al., [58] suggested that lesion colour may be useful when selecting lines from a population where the major resistance genes segregate. Moreover, they also emphasized on the inclusion of the number of uredinia per lesion, frequency of lesions having uredinia, frequency of open uredinia and level of sporulation in the selection criteria to reliably assign soybean genotypes as resistant or susceptible against SBR. Noticeably, the number of uredinia per lesion and the level of sporulation do not necessarily correlate with lesions colour indicating that these traits are inherited independently in soybean $[29,73]$. Therefore, inclusion of such additional traits especially number and size of uredinia, and level of severity and sporulation may be more informative than lesion colour alone. 


\section{Genetics of Resistance to SBR Resistance}

Following an epidemic of SBR in the early 1970s in India, Singh and Thapliyal [92] conducted a genetic study of SBR using field screening of an $\mathrm{F}_{2}$ population derived from UPSS3 and Clark 63, and observed a monogenic ratio with resistance being dominant. These results reaffirmed the principles of Mendelian inheritance of rust resistance in soybean. Subsequently, Bromfield and Hartwig in the USA [49] also confirmed monogenic inheritance with a dominant nature for resistance to SBR in soybean accessions PI 230970 and PI 230971. In parallel, McLean and Byth [37] also performed a study in Australia and concluded that a single dominant gene in soybean accession PI 200492, originally from Chiougoku-Shikoku Experimental Station, Shikoku, Japan conferred resistance to the disease and suggested the use of symbol Rpp1 (Resistance to P. pachyrhizi 1) to designate the first rust-resistant gene in soybean. Rpp1 was later mapped to linkage group G, corresponding to chromosome 18 (Table 2) [61].

By 1980, independent research groups from India, the USA, and Australia confirmed that soybean lines PI 462312, PI 200492 and PI 230970 each carry a single dominant gene conferring specific resistance to SBR, but it remained unclear whether those genes were at the same locus. The pioneer genetic study of Hartwig and Bromfield [50] not only confirmed the previously published reports that each soybean line carried a single dominant gene for resistance but also demonstrated that each gene was at a different locus. Moreover, they also showed that each gene confers a different set of host reactions depending on the evaluated P. pachyrhizi isolates and assigned the rust resistance locus in PI 230970 and PI 462312 as Rpp2 and Rpp3, respectively. Further marker-based studies mapped the Rpp2 and Rpp3 loci to linkage groups J and C2, corresponding to soybean chromosomes 16 and 6, respectively [51,72].

Subsequently, it was observed that the soybean accessions containing resistance gene Rpp 1 through Rpp3 (PI 200492, PI 230970, and PI 462312) were susceptible when inoculated with isolate TW80-2 from Taiwan, but that soybean accession PI 459025 was resistant to it. On the basis of reaction of progenies derived from the crosses involving PI 459025 with each of the three previously identified sources of Rpp1, Rpp2, and Rpp3, with a set of different rust differentials, Hartwig [79] concluded that PI 459025 also contains a single dominant gene for rust resistance which is at a different locus from the previously identified rust resistant genes (Rpp1, Rpp2 and Rpp3) and designated it as Rpp4, fourth major gene, which confers resistance to the disease. Later, the locus Rpp4 was mapped to linkage group G (chromosome 18) by Silva et al., [72].

Following the outbreak of SBR in South America in early 2000s, the disease posed potentially devastating risk when resistance conferred by two well-known rust resistant loci, Rpp1 and Rpp3 were simultaneously defeated by P. phakopsora isolate in Mato Grosso State in Brazil [71,93]. Thus, further investigation had to focus on the inheritance of rust resistance in soybean lines which were reported or identified as source of SBR resistance genes during this period. In Brazil, Garcia et al., [71] studied the genetic basis of SBR resistance in five $\mathrm{F}_{2}$ populations derived from crosses involving a Brazilian-adapted soybean cultivar CD 208 (susceptible) to each of five different resistant lines (PI 200487, PI 200526, PI 230970, PI 459025, and PI 471904). The strategy led to the identification of a new SBR resistance locus on linkage group N (chromosome 3) in PI 200456 and referred to as rpp5. Interestingly, the locus showed distinct types of gene action (dominance, incomplete dominance and recessive) for SBR resistance in three different soybean lines PI 200526, PI 471904, and PI 200456, indicating the existence of either multiple alleles or closely linked genes at this locus [70].

Following the SBR outbreak in the USA during 2004, it was felt that evaluation of soybean lines should be performed with SBR isolates and populations from the USA, because earlier studies on SBR resistance had been performed with only foreign P. pachyrhizi isolates [94-96]. Li et al., [60] developed a mapping population from a cross between accession PI 567102B from Indonesia, which was previously identified as resistant to P. pachyrhizi isolates from Paraguay [97] and the USA [98], with the SBR-susceptible soybean breeding line DS- 880 from the USA. Their results showed that resistance in PI 567102B was controlled by a single dominant gene at a different locations than either Rpp1 or Rpp4 on chromosome 18 (linkage group G) and proposed this gene as Rpp6. More recently, Childs et al., [57] also identified a new resistance locus in soybean accession PI 605823 from Vietnam 
that confers resistance to the USA isolate GA12. The new locus was designated as Rpp 7 and mapped to a 0.8-cM (154 kb) region on chromosome 19 (Table 2).

Multiple alleles of Rpp genes exist in soybean genomes, which show differential responses to selected P. pachyrhizi pathotypes or demonstrate different gene actions $[56,62,71,77,82]$. For instance, Chakraborty et al., [62] showed that a P. pachyrhizi isolate from Zimbabwe (ZM01-1) produced RB lesions on soybean line PI 594538A, but TAN lesions on PI 200492, the original source of Rpp1. Further genetic analysis suggested that there is either another gene closely associated with Rpp1 or different alleles of Rpp1 gene exists in PI 594538A, because the resistance gene was mapped in the Rpp1 locus. Thus, a new allele designation was proposed as Rpp1b. Similarly, Ray et al., [52] also mapped resistance genes from soybean accessions PI 587880A and PI 587886 in the Rpp 1 locus that have different specificities than $R p p 1$ and $R p p 1 b$. The authors suggested the presence of an alternative allele of Rpp1 in these genotypes which showed immunity in the homozygous state whereas RB lesions in case of the heterozygous condition, but TAN lesions in the homozygous state of the other allele. A perusal of Table 1 also suggests that either multiple genes closely associated with these Rpp loci and/or different alleles of these Rpp genes exist, especially at $R p p 1$ and also at $R p p 3, R p p 4$ and Rpp5, because the same pathotype exhibited contrasting reaction behaviour (TAN to RB or IR reaction) to different differential sets containing the same Rpp gene. Moreover, the presence of additional QTLs (quantitative trait loci) conferring resistance can also not be ruled out in some of these lines belonging to the same $R p p$ differential set, though segregation ratios usually fit numbers expected for segregation of a single major resistance gene.

\section{Molecular Investigations of Soybean Resistance to P. pachyrhizi}

Soybean germplasm screening efforts have led to the identification of several sources of resistance to $P$. pachyrhizi, but as described previously, molecular mapping analyses have so far identified seven loci (Rpp1 to Rpp7; Table 2), that provide varying degrees of resistance to P. pachyrhizi. However, none of them has been cloned. Based on the soybean reference genome, all the known Rpp loci except Rpp5 and Rpp6 seem to contain clusters of genes encoding NLR (nucleotide-binding domain, leucine rich) proteins (Rpp1/Rpp1b-NLR, Rpp2-TIR-NLR, Rpp3-TIR-NLR, Rpp4-CC-NLR, Rpp7-NLR) [57,99]. However, only Rpp1 and Rpp 4 have been so far shown unequivocally to be encoded by a member of the associated NLR cluster.

Thus far, the identity of the effectors or other determinants that contribute to the recognition of P. pachyrhizi isolates in soybean remain unidentified. At molecular level, virus-induced gene silencing (VIGS) technology played a major role in the molecular diagnosis of resistance employed by soybean against $P$. pachyrhizi. Meyer et al., [80] identified the first candidate gene governing rust resistance in soybean from P. pachyrhizi resistant accession PI 459025B (Rpp4) through a combination of DNA sequencing, gene expression analysis and VIGS. In susceptible cultivar Williams 82 , three genes in the CC-NBS-LRR (coiled-coil, nucleotide binding site, leucine-rich repeat) family of R genes were identified at the Rpp4 locus, which revealed similarity with the Rgc2 (Resistant Gene Candidate2) R gene family in lettuce. However, these genes had different alleles in resistant accession PI 459025B, and one allele (Rpp4C4) was predominantly expressed in resistant plants before and after challenge with P. pachyrhizi isolate LA04-1 that produced only RB lesions. The silencing of CC-NBS-LRR R gene resulted in the loss of resistance, indicating that this gene is the causal candidate in the Rpp 4 gene cluster.

More recently, Pedley et al., [100] also used VIGS to functionally characterize the Rpp1 locus immunity. Rpp 1 is located on chromosome 18 in a region spanning approximately $150 \mathrm{~kb}$ between markers Sct_187 and Sat_064 in L85-2378 (Rpp1), an isogenic line developed from soybean cultivar Williams 82 and accession PI 200492, the original source of Rpp1. The authors constructed a BAC library for PI 200492 and sequenced the Rpp 1 locus, leading to the identification of three homologous NBS-LRR genes. Each candidate gene is also predicted to encode an N-terminal ULP1 (ubiquitin-like protease 1) domain. The co-silencing of these candidate genes abrogated the immune response in the 
Rpp1 resistant soybean accession PI 200492, but not defence, indicating that Rpp1 is a ULP1-NBS-LRR protein and plays a key role in the immune response.

In order to understand the gene networks regulating soybean P. pachyrhizi interactions, genome-wide transcriptome and proteome studies have been performed [101]. Differential gene expression experiments clearly revealed that a biphasic transcriptional response to infection operates in both compatible and incompatible soybean-P. pachyrhizi interactions [80,102-105]. The first phase begins about $12 \mathrm{~h}$ after inoculation (hai) with a non-specific recognition pattern in both susceptible and resistant genotypes. The second transcriptional upregulation phase occurs about 72 hai with a specific recognition pattern only in resistant genotypes; in susceptible genotypes this phase remains mainly unaffected, but if occurs at all it may be very weak and only much later. Morales et al., [105] identified fourteen transcription factors (TFs) unique to R-gene-mediated resistance responses through comparative microarray datasets generated from Rpp2-, Rpp3- and Rpp4-mediated disease resistance lines which clearly indicated the important role of TFs in conferring resistance to SBR, but the efforts unlikely clarified the mechanism of Rpp mediated resistance.

Based on transcriptome and metabolome analyses, Ishiga et al., [106] revealed the vital role of phytoalexins such as phenylpropanoids, and (iso)flavonoids in $M$. truncatula to confer non-host resistance against SBR. This involves the induction of phenylpropanoid pathway genes during infection in Rpp2-mediated disease resistance in soybean against SBR [102]. More recently, Hossain et al., [107] performed a transcriptome study of SBR-susceptible soybean genotype BRS184 and NIL (Near Isogenic Line) for the Rpp 3 gene with SBR isolate T1-2 at 24 hai and revealed that $52 \%$ of the phenylpropanoid pathway related genes were upregulated. Subsequently, the RT-qPCR-based transcript analysis of selected genes of phenylpropanoid pathway from NILs for Rpp1, Rpp2, Rpp3, and Rpp4 together with recurrent parent, BRS184 at 0 hai to 96 hai revealed greatest expression of all the studied genes at 12 hai except glycinol 4-dimethylallyltransferase (G4DT) and chalcone reductase (CHR) suggesting the Rpp NILs utilized these genes in a rate limiting manner as a defence response, but the gene expression patterns which occur between 24 and 96 hai make these Rpp lines unique to their respective SBR isolates [107].

\section{SBR Management Through Genetic Strategies}

\subsection{Single Gene Deployment and Their Continuous Replacement}

Generally, deployment of a single major gene is not advocated by breeders or pathologists for controlling plant diseases [34]. However, in some pathosystems, a single resistance gene has proved efficient and durable even in polygenic, quantitative disease tolerance [93,108]. Owing to the difficulty to incorporate quantitative resistance into soybean breeding programmes, identifying SBR tolerant lines in soybean germplasm became a priority. Two soybean varieties, 'Lu Pi Dou' and 'Hei Dou' from China presented leaf-yellowing prevention characteristic when inoculated with pathogenic isolates that generally promote early leaf-yellowing and defoliation [90]. Both varieties developed TAN lesions following infection with the BPR-2 isolate which clearly suggests that the major Rpp genes are either absent or ineffective to the isolate if present in these varieties, though information on genetic basis of the characteristic of leaf-yellowing prevention is still lacking [109]. Martins and Juliatti [110] concluded that partial resistance to SBR is a characteristic controlled by 2 to 23 genes, but an elaborate strategy is required to combine such large numbers of genes having minor effects [93].

Considering the high pathogenic variability and the emergence of new pathotypes in field populations of P. pachyrhizi, it is desirable and feasible to develop soybean cultivars carrying broad spectrum resistance to SBR, but there is also growing evidence for the selection of pathogen genotypes able to overcome quantitative resistance [111]. Nonetheless, in spite of the well-known short-lived effectiveness of host resistance to pathotype-specific genes, the deployment of a single major gene may make sense for soybean growing regions where the environment is less conducive to SBR and where there are limited alternative hosts for the pathogen that may owe to smaller amounts of pathogen 
inoculum. Moreover, monogenic rust resistance could be more durable for environments in which a disease occurs at moderate or low severity where a single resistance gene may be adequate for a longer period of time, freeing resources to breed for durability to more serious/frequent diseases. In the past, the best example is the soybean cultivars carrying Rpp1 and Rpp3 genes which remained effective in Brazil against rust for several years after field release until highly virulent Brazilian P. pachyrhizi population emerged in the state of Mato Grosso in 2003 [112].

Since pathogen co-evolution is defeating current resistance genes, the continuous identification of novel disease resistance genes is not only of paramount importance, but their effective deployment and replacement of existing resistance genes after appearance of virulent races are also highly crucial. Such strategies have been successfully implemented in rice against tungro and blast disease $[113,114]$.

\subsection{Gene Pyramiding}

Pyramiding is the deployment of multiple genes into a single genotype resulting in the simultaneous expression of these genes in the host. For durable resistance, a pyramid could be constructed with any type of host genes including major/minor genes, (in) effective genes, (non)race-specific genes that confer resistance [34,115]. However, the accumulation of several resistance genes with homozygous conditions in a specific background could be a major problem in conventional breeding, because the number of isolates required to distinguish a specific resistance gene becomes more complicated after three genes [115].

With the advent of molecular markers, tagging of genes or loci involved in the variation of quantitative traits through QTL mapping became feasible. Marker-assisted selection makes gene pyramiding possible and more efficient [34]. Notably, it has also been observed that some soybean accessions contain more than one Rpp genes. Screening of Hyuuga (PI 506764)-derived recombinant inbred lines indicated that Hyuuga carries two resistance genes, one at the Rpp3 locus and another at the Rpp5 locus [53]. Similarly, two rust resistant soybean genotypes, EC 241780 from USA and DT 2000 (PI 635999), a selection from the breeding line GC 00138-29, developed by the Asian Vegetable Research and Development Center (AVRDC) in Taiwan, also provide interesting sources for the study of natural gene pyramiding in soybean, as each genotype carry two Rpp genes (Rpp $1 b$ and Rpp2) and (Rpp3 and Rpp4), respectively [66,78].

Breeding for SBR resistance has become an important aspect of many soybean improvement programmes, and would be augmented by the identification of genes and/or loci conditioning SBR resistance in a wide range of soybean varieties. To date, seven genes/loci (Rpp1 to Rpp 7) against numerous specific pathotypes of SBR have been identified in global soybean germplasm (Table 2) but were found to be ineffective when challenged with other pathotypes. Therefore, pyramiding of available Rpp genes in a single genotype is expected to provide broad-spectrum and higher level of resistance due to the buffering effects of multiple genes against SBR.

In soybean, pyramiding of Rpp2, Rpp4, and Rpp5 in a single genotype was shown to provide higher resistance to SBR $[73,116]$. Similarly, pairwise gene pyramiding of Rpp2, Rpp3 and Rpp4 also reduced SBR severity and sporulation [117]. Yamanaka et al., [68] also demonstrated significantly higher resistance to SBR in the Rpp pyramided lines No6-12-B, Oy49-4 and No6-12-1 containing two $(R p p 4+R p p 5)$, three $(R p p 2+R p p 3+R p p 4)$, and three $(R p p 2+R p p 4+R p p 5)$ genes, respectively when compared to the original resistance sources carrying single genes, PI 230970 (Rpp2), Hyuuga (Rpp3), PI 459025 (Rpp4), and Kinoshita (Rpp5). Interestingly, the pyramided line No6-12-1 was resistant to all the four P. pachyrhizi populations from Mexico, but none of the differentials carrying a single Rpp gene showed resistance to all those P. pachyrhizi populations [45]. These results clearly show the potential of pyramided lines carrying Rpp gene combinations that can circumvent the breakdown of single-gene resistance and offers a broad-spectrum resistance against SBR. It is quite evident that the durability of race-specific resistance genes is often limited, thus, the information on gene action types of resistance of Rpp genes and their relative contribution for disease resistance in a pyramided line is highly relevant 
for assessing the durability of gene pyramiding. Unfortunately, experimental data on such aspects for SBR pyramided lines is very scarce.

There is also growing evidence that different resistance genes contribute in a disproportionate manner to disease resistance and genetic background also plays an important role in their activity [108]. An effect of genetic background has been observed on genetic behaviour of Rpp 1 locus in populations derived from the cross of SBR resistant accessions crossed with different susceptible parents [63]. Maphosa et al., [117] observed complementary epistatic gene action for rust resistance in the Rpp2, Rpp3 and Rpp4 pair wise gene pyramiding. Interestingly, the Rpp3 gene contributed more to resistance than the Rpp 2 and $R p p 4$ genes in various genetic backgrounds.

\subsection{Non-Host Resistance}

The intrinsic property of a plant or animal species to resist the establishment and multiplication of all races of a potential pathogen is referred to as non-host resistance (NHR) [118]. NHR is considered as most durable and effective, probably because it relies on multiple protective mechanisms that comprise both constitutive barriers and inducible reactions which are not easy to overcome by a pathogen [119]. Generally, NHR operates at two stages: pre- and post-invasive resistance. Pre-invasive resistance includes preformed physical or chemical barriers on the host surface that restrict the establishment of non-host pathogens, whereas post-invasive resistance limits the penetration and multiplication of non-host pathogens through diverse mechanisms that include local and systemic immune responses. Thus, pre-invasive resistance can be either passive or active, but post-invasive resistance is an active defence response in which infection is followed by symptom development such as hypersensitive responses (e.g., programmed cell death and reactive oxygen species accumulation) [120].

Langenbach et al., [121] identified the gene for UDP glycosyltransferase 84A2 (UGT84A2 or Bright Trichomes1 (BRT1)) as a critical component of Arabidopsis thaliana post-invasion NHR to P. pachyrhizi, but the role of BRT1 in resistance to P. pachyrhizi in soybean still needs validation. Subsequently, the author's identified ten additional Post-invasion Induced Nonhost resistance Genes (PINGs) that transcriptionally co-regulated with BRT1 in Arabidopsis upon P. pachyrhizi infection and analyzed their contribution to Arabidopsis NHR by dsRNAi-mediated gene silencing in the pen 2 genetic background in Arabidopsis. They also assessed SBR resistance in soybean by overexpressing independently NHR-linked Arabidopsis genes (PINGs) in SBR-susceptible soybean cultivar Williams 82 [122]. Among the ten PINGs, only PING4, PING5 and PING9 were essential to Arabidopsis post-invasion NHR to P. pachyrhizi and conferred enhanced resistance to the SBR pathogen (P. pachyrhizi). On the other hand, overexpression of PING7 induced increased resistance to P. pachyrhizi in transgenic lines compared to control, however, its silencing in Arabidopsis did not lead to increased susceptibility to the pathogen, possibly because of functional redundancy within the large GDSL-motif lipase/hydrolase gene family [122].

Ishiga et al., [106] demonstrated that the $M$. truncatula sgr mutant and alfalfa SGR-RNAi lines showed hypersensitive response (HR)-like enhanced cell death upon inoculation with P. pachyrhizi which suggested the possible role of stay green (SGR) in NHR. Despite the role of SGR as an R gene for SBR resistance not having yet been proven, the characteristic SGR/leaf yellowing prevention slows down the rapid defoliation due to SBR infestation leading to reduction in yield loss [109].

The potential of post-invasive NHR as a disease control strategy has also been validated with the identification and cloning of CcRpp1, an NLR-encoding gene from pigeonpea (C. cajan) that confers resistance against P. pachyrhizi when expressed in soybean [123]. Pigeonpea, a close relative of soybean, is a diploid, self-pollinating legume crop displaying a wide array of disease reactions ranging from immunity to partial infection similar to soybean when challenged with P. pachyrhizi [123].

\section{Strategies for Achieving Higher Durability of SBR Management}

During the third quarter of 20th century, a plethora of terms (e.g., horizontal, poly/multi-genic, partial, minor gene; race nonspecific) were used to define the quantitative resistance which is generally considered as durable resistance in scientific debates. Although it is difficult to precisely recognize 
the durable resistance with absolute certainty, Johnson [124] defined durable resistance from disease management perspectives as the resistance that lasts effectively when deployed over extensive acreage and time, in an environment favourable for the disease. Until now, no phenotype of the plant or the plant-pathogen interaction has been clearly identified that defines a source of resistance as being potentially durable, though, it is generally considered that such resistance tends to be based on the additive effect of several resistance genes, each conferring a partial resistance with the hope that such types of resistance will remain effective for a longer period.

So far, as shown above, only seven Rpp loci (Table 2) have been identified in soybean which have proven to be pathotype/race-specific, with the resistance being effective only against isolates of P. pachyrhizi carrying the corresponding avirulence gene. This type of resistance complies with the description of the gene-for-gene hypothesis first proposed by Flor [125] in the flax-flax rust (Melampsora lini) interaction. Therefore, an integrated long-term management strategy needs to be developed for the enhancement of durability of SBR resistance which may include combination of genetic approach, crop management practices, biological and chemical control measures.

\subsection{Genetic Approach}

A continuous search for new breeding resources of resistance is an essential component of disease management through genetic approaches. Besides cultivated soybean (Glycine max), several accessions within other Glycine species such as G. argyrea, G. canescens, G. clandestina, G. latifolia, G. microphylla, G. tomentella and G. tabacina have shown to contain resistance to SBR [126,127]. The wild perennial Glycine species are potentially rich sources of resistance to SBR, but due to the difficulties in attempting hybridizations with cultivated soybean, ploidy level differences and undesirable traits impede their direct utilization in conventional breeding. Therefore, it would be desirable to dissect the genetic factors responsible for SBR resistance in these useful resources, so that the desirable gene/alleles from such material could be transferred into elite germplasm through QTL introgression, marker assisted selection, and other genomic approaches [128].

Once an SBR resistant cultivar/line is developed through either conventional, gene editing or transgenic approaches, the deployment of such cultivars (each cultivar having different genetic make-up as well as containing individual or a set of different resistance genes) or multi-lines (several lines having the same genetic make-up except bearing different resistance genes) at individual farm or regional level could be a cornerstone of disease resistance durability [111,129,130].

\subsection{Crop Management Practices}

So far, very few agronomic practices have been reported for SBR management. Moreover, such practices are restricted to specific sites and/or climatic zones and are mainly dependent on disease avoidance mechanisms. For instance, preferential sowing of soybean during dry season in Nigeria and if sown during the wet season, then early planting appeared as important factor to avoid SBR incidence [12]. Similarly, substantial reduction in rust incidence appeared during the main season in Brazil when a 90-day soybean free period was enforced during the off-season [13]. A survey of the literature indicates that most agronomic practices such as row spacing, sowing date, cultivar maturity and cropping and tillage system, does not directly affect SBR incidence or severity; however, such practices may influence disease pressure due to extended time that the crop is exposed in the field.

Besides agronomic practices, foliar application of some natural compounds such as Farnesyl-acetate [131], Acibenzolar-S-methyl [132], essential oils from H. marrubioides, A. gratissima, and C. verbenacea [133], coffee oil [134]; seed treatment with shale water [135]; root drenching with saccharin [136] were also reported to be effective in the suppression of SBR severity, but their actual efficacy for effective SBR control is still awaiting assessment under field conditions.

Besides the beneficial effects on plant growth and yield, silicon ( $\mathrm{Si}$ ) is also gaining recognition for its prophylactic role in alleviating diseases, insect attack, unfavourable climatic conditions, and in improvement of the physical and chemical soil properties [137]. The use of soil- and/or foliar-applied 
silicon (Si) has reduced SBR disease severity up to $65 \%$ as well as delaying the disease onset $[138,139]$. Moreover, Arsenault-Labrecque et al., [140] showed that there is genetic variability for Si absorption within soybean germplasm and high absorption of Si protects the soybean crop against SBR disease through mediated resistance. In future, studies will be required to understand the mechanisms by which Si boosts SBR disease resistance in soybean. Moreover, prior to widespread use of Si in soybean, additional information, such as appropriate source of $\mathrm{Si}$ and its mode of application are also needed for more precise and long-lasting control of P. pachyrhizi.

\subsection{Biological and Chemical Control}

The biocontrol of SBR lacks thorough studies, though some mycoparasites such as Trichothecium rosae and Simplicillium lanosoniveum seem to be potential biocontrol agents which showed clear effect on the germination of P. pachyrhizi uredospores and also reduced both sporulation and disease severity [141,142]. In addition, Bacillus species could be the major sources of microbial biopesticides due to their valuable characteristics. Dorighello et al., [134] observed reduction in rust severity as well as complete inhibition in the germination of P. pachyrhizi uredospores with the application of B. subtilis and B. pumilus. Nonetheless, even though application of biological agents holds promise for sustainable management of SBR, progress in this direction needs to be followed up in the future with more experimental evidence.

Considering the points discussed above, a combination of spatial deployment of resistant cultivars/multi-lines together with crop management practices and biological control may offer the best way to maximize the durability of rust resistance in soybean. The application of fungicides is one of the most critical decisions and should be applied only when cultivar resistance has completely broken down, and/or when rust inoculum starts to build up rapidly in the field, because most fungicides will control rust for only 2 to 3 weeks.

\section{Concluding Remarks}

SBR caused by two different species, P. pachyrhizi and P. meibomiae, is considered the most devastating disease of soybeans worldwide. It is well accepted that the more virulent of the two species is P. pachyrhizi, a pathogen native to Asia-Australia which has dispersed beyond its traditional range due to its capability to produce enormous numbers of wind-dispersed urediniospores, and multiple infection cycles can take place within a single growing season. Since a rust pathogen is an obligate biotrophic parasite, the genetic characteristics of the Phakopsora isolates are most difficult to monitor outside its host. Therefore, any resistance genes in host cultivars that restrict or eradicate the rust development will result in enormous selection pressure for pathotypes that are virulent to the resistance genes.

The deployment of resistant cultivars is the most sustainable method for disease control including SBR, but none of the Rpp genes conferring resistance to P. pachyrhizi identified so far in soybean germplasm are effective against all the reported pathotypes of this fungus. Moreover, the resistance of P. pachyrhizi to fungicides, together with evolution of new virulent races, suggest that no single strategy will be able to maintain the sustainability of the crop. Since the availability of resistant cultivars holds the promise for more precise and long-lasting control of SBR in soybean, it is necessary to continue conducting research on genetic approaches for resistant gene identification, their effective deployment and the strategies that enhance the durability of disease resistance genes in such cultivars. Finally, it may be necessary to use fungicides when needed to minimize the economic losses incurred by this fungus and to keep a functional industry until such time that more durable strategies can be developed.

Author Contributions: S.C. prepared original draft, A.O.-B. and R.B. provided input on epidemiology and pathogenicity section, P.S. improved the cultural management section, G.O.I. assisted in compilation of information and preparation of tables, M.W.V. provided inputs to the different sections of the manuscript especially molecular aspects with A.L.G.-O and, A.L.G.-O. coordinated, finalized and submitted the manuscript. All authors have read and approved the final manuscript 
Funding: This research received no external funding.

Acknowledgments: S.C. thanks Robert Asiedu, G. Chigeza and M. Gedil (IITA) for their kind support. G.O.I. appreciates African Union for her PhD fellowship. M.W.V. acknowledges the support of FCT (UID/Multi/50016/2019) and ESF through the Northern Operational Program-Norte2020 (NORTE-08-5369-FSE-000007). We acknowledge Kenton Dashiell (IITA) for reviewing the overall manuscript as well anonymous reviewers for their valuable comments and suggestions.

Conflicts of Interest: The authors declare no conflict of interest.

\section{References}

1. Hymowitz, T. The history of the soybean. In Soybeans: Chemistry, Production, Processing, and Utilization; Johnson, L.A., White, P.J., Galloway, R., Eds.; AOCS Press: Urbana, IL, USA, 2008; pp. 1-31.

2. Hartman, G.L.; Sinclair, J.B.; Rupe, J.C. Compendium of Soybean Diseases, 4th ed.; American Phytopathological Society Press: St Paul, MN, USA, 1999.

3. Oerke, E.C. Crop losses to pests. J. Agric Sci. 2006, 144, 31-43. [CrossRef]

4. Hartman, G.L.; West, E.D.; Herman, T.K. Crops that feed the World 2. Soybean-Worldwide production, use, and constraints caused by pathogens and pests. Food Secur. 2011, 3, 5-17. [CrossRef]

5. Li, X.; Esker, P.D.; Pan, Z.; Dias, A.P.; Xue, L.; Yang, X.B. The uniqueness of the soybean rust pathosystem: An improved understanding of the risk in different regions of the world. Plant Dis. 2010, 94, 796-806. [CrossRef] [PubMed]

6. Isard, S.A.; Gage, S.H.; Comtois, P.; Russo, J.M. Principles of the atmospheric pathway for invasive species applied to soybean rust. BioScience 2005, 55, 851-861. [CrossRef]

7. Goellner, K.; Loehrer, M.; Langenbach, C.; Conrath, U.W.E.; Koch, E.; Schaffrath, U. Phakopsora pachyrhizi, the causal agent of Asian soybean rust. Mol Plant Pathol. 2010, 11, 169-177. [CrossRef] [PubMed]

8. Hartman, G.L.; Wang, T.C.; Tschanz, A.T. Soybean rust development and the quantitative relationship between rust severity and soybean yield. Plant Dis. 1991, 75, 596-600. [CrossRef]

9. Miles, M.R.; Frederick, R.D.; Hartman, G. Soybean rust: Is the U.S. soybean crop at risk. In APSnet Feature; American Phytopathological Society: St. Paul, MN, USA, 2003. [CrossRef]

10. Hartman, G.L.; Miles, M.R.; Frederick, R.D. Historical viewpoint and soybean resistance to soybean rust. In Proceedings of the 2005 Illinois Crop Protection Conference, Urbana, IL, USA, 5-6 January 2005; pp. 16-20.

11. Desborough, P.J. Selection of soybean cultivar and sowing date as a strategy for avoidance of rust (Phakopsora pachyrhizi Syd.) losses in coastal New South Wales. Aust. J. Exp. Agric. 1984, 24, 433-439. [CrossRef]

12. Twizeyimana, M.; Ojiambo, P.S.; Hartman, G.L.; Bandyopadhyay, R. Dynamics of soybean rust epidemics in sequential plantings of soybean cultivars in Nigeria. Plant Dis. 2011, 95, 43-50. [CrossRef]

13. Godoy, C.V.; Seixas, C.D.S.; Soares, R.M.; Marcelino-Guimarães, F.C.; Meyer, M.C.; Costamilan, L.M. Asian soybean rust in Brazil: Past, present, and future. Pesquisa Agropecuária Brasileira 2016, 51, 407-421. [CrossRef]

14. Aime, M.C.; McTaggart, A.R.; Mondo, S.J.; Duplessis, S. Phylogenetics and phylogenomics of rust fungi. Adv. Genet. 2017, 100, 267-307.

15. Lorrain, C.; Gonçalves dos Santos, K.C.; Germain, H.; Hecker, A.; Duplessis, S. Advances in understanding obligate biotrophy in rust fungi. New Phytol. 2019, 222, 1190-1206. [CrossRef] [PubMed]

16. Bromfield, K.R. Soybean Rust; American Phytopathological Society: St. Paul, MN, USA, 1984.

17. Hennings, P. Einige neue japanische Uredinales (in German). Hedwigia 1903, IV, 107-108.

18. Sydow, H.; Sydow, P. A contribution to knowledge of the parasitic fungi on the island of Formosa. Ann. Mycol. 1914, 12, 105-112.

19. Vakili, N.G.; Bromfield, K.R. Phakopsora rust on soybean and other legumes in Puerto-Rico. Plant Dis. Rep. 1976, 60, 995-999.

20. Bonde, M.R.; Peterson, G.L.; Dowler, W.M. A comparison of isozymes of Phakopsora pachyrhizi from the Eastern Hemisphere and the New World. Phytopathology 1988, 78, 1491-1494. [CrossRef]

21. Ono, Y.; Buritica, P.; Hennen, J.F. Delimitation of Phakopsora, Physopella and Cerotelium and their species on Leguminosae. Mycol. Res. 1992, 96, 825-850. [CrossRef]

22. Frederick, R.D.; Snyder, C.L.; Peterson, G.L.; Bonde, M.R. Polymerase chain reaction assays for the detection and discrimination of the soybean rust pathogens Phakopsora pachyrhizi and P. meibomiae. Phytopathology 2002, 92, 217-227. [CrossRef] 
23. Levy, C. Epidemiology and chemical control of soybean rust in southern Africa. Plant Dis. 2005, 89, 669-674. [CrossRef]

24. Hartman, G.L.; Hill, C.B.; Twizeyimana, M.; Miles, M.R.; Bandyopadhyay, R. Interaction of soybean and Phakopsora pachyrhizi, the cause of soybean rust. CAB Rev. Perspect. Agric. Vet. Sci. Nutr. Nat. Resour. 2011, 6, 59-71. [CrossRef]

25. Killgore, E.; Heu, R.; Gardner, D.E. First report of soybean rust in Hawaii. Plant Dis. 1994, 78, 1216. [CrossRef]

26. Freire, M.C.M.; de Oliveira, L.O.; de Almeida, A.M.R.; Schuster, I.; Moreira, M.A.; Liebenberg, M.M.; Mienie, C.M.S. Evolutionary history of Phakopsora pachyrhizi (the Asian soybean rust) in Brazil based on nucleotide sequences of the internal transcribed spacer region of the nuclear ribosomal DNA. Genet. Mol. Biol. 2008, 31, 920-931. [CrossRef]

27. Stokstad, E. Agriculture-Plant pathologists gear up for battle with dread fungus. Science 2004, 306, 1672-1673. [CrossRef] [PubMed]

28. Schneider, R.W.; Hollier, C.A.; Whitam, H.K.; Palm, M.E.; McKemy, J.M.; Hernández, J.R.; Levy, L.; DeVries-Paterson, R. First report of soybean rust caused by Phakopsora pachyrhizi in the continental United States. Plant Dis. 2005, 89, 774. [CrossRef] [PubMed]

29. Bonde, M.R.; Nester, S.E.; Austin, C.N.; Stone, C.L.; Frederick, R.D.; Hartman, G.L.; Miles, M.R. Evaluation of virulence of Phakopsora pachyrhizi and P. meibomiae isolates. Plant Dis. 2006, 90, 708-716. [CrossRef] [PubMed]

30. Barrus, M.R. Variation of varieties of beans in their susceptibility to anthracnose. Phytopathology 1911, 1, 190-195.

31. Shaner, G.; Stromberg, E.L.; Lacy, G.H.; Barker, K.R.; Pirone, T.P. Nomenclature and concepts of pathogenicity and virulence. Annu. Rev. Phytopathol. 1992, 30, 47-66. [CrossRef] [PubMed]

32. Bos, L.; Parlevliet, J.E. Concepts and terminology on plant/pest relationships: Toward consensus in plant pathology and crop protection. Annu. Rev. Phytopathol. 1995, 33, 69-102. [CrossRef] [PubMed]

33. Zhan, J.; McDonald, B.A. Experimental measures of pathogen competition and relative fitness. Annu. Rev. Phytopathol. 2013, 51, 131-153. [CrossRef] [PubMed]

34. Mundt, C.C. Pyramiding for resistance durability: Theory and practice. Phytopathology 2018, 108, 792-802. [CrossRef] [PubMed]

35. Lin, S.Y. Studies on the physiologic races of soybean rust fungus, Phakopsora pachyrhizi Syd. J. Taiwan Agric. Res. 1966, 15, 24-28.

36. McLean, R.; Byth, D.E. Resistance of soybean to rust in Australia. APPS Newsl. 1976, 5, 34-36. [CrossRef]

37. McLean, R.J.; Byth, D.E. Inheritance of resistance to rust (Phakopsora pachyrhizi) in soybeans. Aust. J. Agric. Res. 1980, 31, 951-956. [CrossRef]

38. Burdon, J.J.; Silk, J. Sources and patterns of diversity in plant-pathogenic fungi. Phytopathology 1997, 87, 664-669. [CrossRef]

39. Wang, X.; McCallum, B. Fusion body formation, germ tube anastomosis, and nuclear migration during the germination of urediniospores of the wheat leaf rust fungus, Puccinia triticina. Phytopathology 2009, 99, 1355-1364. [CrossRef] [PubMed]

40. Vittal, R.; Yang, H.C.; Hartman, G.L. Anastomosis of germ tubes and migration of nuclei in germ tube networks of the soybean rust pathogen, Phakopsora pachyrhizi. Eur. J. Plant Pathol. 2012, 132, 163-167. [CrossRef]

41. McDonald, B.A.; Stukenbrock, E.H. Rapid emergence of pathogens in agro-ecosystems: Global threats to agricultural sustainability and food security. Philos. Trans. R. Soc. B Biol. Sci. 2016, 371, 20160026. [CrossRef]

42. Yamaoka, Y.; Fujiwara, Y.; Kakishima, M.; Katsuya, K.; Yamada, K.; Hagiwara, H. Pathogenic races of Phakopsora pachyrhizi on soybean and wild host plants collected in Japan. J. Gen. Plant Pathol. 2002, 68, 52-56. [CrossRef]

43. Yamaoka, Y.; Yamanaka, N.; Akamatsu, H.; Suenaga, K. Pathogenic races of soybean rust Phakopsora pachyrhizi collected in Tsukuba and vicinity in Ibaraki, Japan. J. Gen. Plant Pathol. 2014, 80, 184-188. [CrossRef]

44. Akamatsu, H.; Yamanaka, N.; Yamaoka, Y.; Soares, R.M.; Morel, W.; Ivancovich, A.J.G.; Bogado, A.N.; Kato, M.; Yorinori, J.T.; Suenaga, K. Pathogenic diversity of soybean rust in Argentina, Brazil, and Paraguay. J. Gen. Plant Pathol. 2013, 79, 28-40. [CrossRef]

45. García-Rodríguez, J.C.; Morishita, M.; Kato, M.; Yamanaka, N. Pathogenic characteristics of the Asian soybean rust (Phakopsora pachyrhizi) in Mexico. Revista Mexicana de Fitopatología 2017, 35, 338-349. 
46. Twizeyimana, M.; Ojiambo, S.; Sonder, K.; Ikotun, T.; Hartman, G.L.; Bandyopadhyay, R. Pathogenic variation of Phakopsora pachyrhizi infecting soybean in Nigeria. Phytopathology 2009, 99, 353-361. [CrossRef] [PubMed]

47. Murithi, H.M.; Haudenshield, J.S.; Beed, F.; Mahuku, G.; Joosten, M.H.A.J.; Hartman, G.L. Virulence diversity of Phakopsora pachyrhizi isolates from East Africa compared to a geographically diverse collection. Plant Dis. 2017, 101, 1194-1200. [CrossRef] [PubMed]

48. Hossain, M.M.; Yamanaka, N. Pathogenic variation of Asian soybean rust pathogen in Bangladesh. J. Gen. Plant Pathol. 2019, 85, 90-100. [CrossRef]

49. Bromfield, K.R.; Hartwig, E.E. Resistance to soybean rust [Phakopsora pachyrhizi] and mode of inheritance. Crop Sci. 1980, 20, 254-255.

50. Hartwig, E.E.; Bromfield, K.R. Relationships among three genes conferring specific resistance to rust in soybeans. Crop Sci. 1983, 23, 237-239. [CrossRef]

51. Hyten, D.L.; Smith, J.R.; Frederick, R.D.; Tucker, M.L.; Song, Q.; Cregan, P.B. Bulked segregant analysis using the GoldenGate assay to locate the locus that confers resistance to soybean rust in soybean. Crop Sci. 2009, 49, 265-271. [CrossRef]

52. Ray, J.D.; Morel, W.; Smith, J.R.; Frederick, R.D.; Miles, M.R. Genetics and mapping of adult plant rust resistance in soybean PI 587886 and PI 587880A. Theor. Appl. Genet. 2009, 119, 271-280. [CrossRef]

53. Kendrick, M.D.; Harris, D.K.; Ha, B.K.; Hyten, D.L.; Cregan, P.B.; Frederick, R.D.; Boerma, H.R.; Pedley, K.F. Identification of a second Asian soybean rust resistance gene in Hyuuga soybean. Phytopathology 2011, 101, 535-543. [CrossRef]

54. Harris, D.K.; Kendrick, M.D.; King, Z.R.; Pedley, K.F.; Walker, D.R.; Cregan, P.B.; Buck, J.W.; Phillips, D.V.; Li, Z.; Boerma, H.R. Identification of unique genetic sources of soybean rust resistance from the USDA soybean germplasm collection. Crop Sci. 2015, 55, 2161-2176. [CrossRef]

55. Paul, C.; Frederick, R.D.; Hill, C.B.; Hartman, G.L.; Walker, D.R. Comparison of pathogenic variation among Phakopsora pachyrhizi isolates collected from the United States and international locations, and identification of soybean genotypes resistant to the US isolates. Plant Dis. 2015, 99, 1059-1069. [CrossRef]

56. King, Z.R.; Childs, S.P.; Harris, D.K.; Pedley, K.F.; Buck, J.W.; Boerma, H.R.; Li, Z. A new soybean rust resistance allele from PI 423972 at the Rpp 4 locus. Mol. Breed. 2017, 37, 62. [CrossRef]

57. Childs, S.P.; King, Z.R.; Walker, D.R.; Harris, D.K.; Pedley, K.F.; Buck, J.W.; Boerma, H.R.; Li, Z. Discovery of a seventh Rpp soybean rust resistance locus in soybean accession PI 605823. Theor. Appl. Genet. 2018, 131, 27-41. [CrossRef] [PubMed]

58. Yamanaka, N.; Yamaoka, Y.; Kato, M.; Lemos, N.G.; Passianotto, A.L.D.L.; dos Santos, J.V.; Benitez, E.R.; Abdelnoor, R.V.; Soares, R.M.; Suenaga, K. Development of classification criteria for resistance to soybean rust and differences in virulence among Japanese and Brazilian rust populations. Trop. Plant Pathol. 2010, 35, 153-162. [CrossRef]

59. Pham, T.A.; Miles, M.R.; Frederick, R.D.; Hill, C.B.; Hartman, G.L. Differential responses of resistant soybean entries to isolates of Phakopsora pachyrhizi. Plant Dis. 2009, 93, 224-228. [CrossRef] [PubMed]

60. Li, S.; Smith, J.R.; Ray, J.D.; Frederick, R.D. Identification of a new soybean rust resistance gene in PI 567102B. Theor. Appl. Genet. 2012, 125, 133-142. [CrossRef] [PubMed]

61. Hyten, D.L.; Hartman, G.L.; Nelson, R.L.; Frederick, R.D.; Concibido, V.C.; Narvel, J.M.; Cregan, P.B. Map location of the locus that confers resistance to soybean rust in soybean. Crop Sci. 2007, 47, 837-840. [CrossRef]

62. Chakraborty, N.; Curley, J.; Frederick, R.; Hyten, D.; Nelson, R.; Hartman, G.; Diers, B. Mapping and confirmation of a new allele at Rpp1 from soybean PI 594538A conferring RB lesion-type resistance to soybean rust. Crop Sci. 2009, 49, 783-790. [CrossRef]

63. Garcia, A.; Calvo, É.S.; de Souza Kiihl, R.A.; Souto, E.R.D. Evidence of a susceptible allele inverting the dominance of rust resistance in soybean. Crop Sci. 2011, 51, 32-40. [CrossRef]

64. Kim, K.S.; Unfried, J.R.; Hyten, D.L.; Frederick, R.D.; Hartman, G.L.; Nelson, R.L.; Song, Q.; Diers, B.W. Molecular mapping of soybean rust resistance in soybean accession PI 561356 and SNP haplotype analysis of the Rpp1 region in diverse germplasm. Theor. Appl. Genet. 2012, 125, 1339-1352. [CrossRef]

65. Hossain, M.M.; Akamatsu, H.; Morishita, M.; Mori, T.; Yamaoka, Y.; Suenaga, K.; Soares, R.M.; Bogado, A.N.; Ivancovich, A.J.G.; Yamanaka, N. Molecular mapping of Asian soybean rust resistance in soybean landraces PI 594767A, PI 587905 and PI 416764. Plant Pathol. 2015, 64, 147-156. [CrossRef]

66. Bhor, T.J.; Chimote, V.P.; Deshmukh, M.P. Molecular tagging of Asiatic soybean rust resistance in exotic genotype EC 241780 reveals complementation of two genes. Plant Breed. 2015, 134, 70-77. [CrossRef] 
67. Yamanaka, N.; Hossain, M.M.; Yamaoka, Y. Molecular mapping of Asian soybean rust resistance in Chinese and Japanese soybean lines, Xiao Jing Huang, Himeshirazu, and Iyodaizu, B. Euphytica 2015, 205, 311-324. [CrossRef]

68. Yamanaka, N.; Morishita, M.; Mori, T.; Lemos, N.G.; Hossain, M.M.; Akamatsu, H.; Kato, M.; Yamaoka, Y. Multiple Rpp-gene pyramiding confers resistance to Asian soybean rust isolates that are virulent on each of the pyramided genes. Trop. Plant Pathol. 2015, 40, 283-290. [CrossRef]

69. Rocha, G.A.F.; Alves, D.P.; Oliveira, J.C.; Brommonschenkel, S.H. Identification and mapping of resistance genes to Phakopsora pachyrhizi in soybean (Glycine max L.) accession PI 594767-A. Genet. Mol. Res. 2016, 15, 1-15. [CrossRef] [PubMed]

70. Calvo, É.S.; Kiihl, R.A.; Garcia, A.; Harada, A.; Hiromoto, D.M. Two major recessive soybean genes conferring soybean rust resistance. Crop Sci. 2008, 48, 1350-1354. [CrossRef]

71. Garcia, A.; Calvo, E.S.; de Souza Kiihl, R.A.; Harada, A.; Hiromoto, D.M.; Vieira, L.G.E. Molecular mapping of soybean rust (Phakopsora pachyrhizi) resistance genes: Discovery of a novel locus and alleles. Theor. Appl. Genet. 2008, 117, 545-553. [CrossRef]

72. Silva, D.C.; Yamanaka, N.; Brogin, R.L.; Arias, C.A.; Nepomuceno, A.L.; Di-Mauro, A.O.; Pereira, S.S.; Nogueira, L.M.; Passianotto, A.L.; Abdelnoor, R.V. Molecular mapping of two loci that confer resistance to Asian rust in soybean. Theor. Appl. Genet. 2008, 117, 57-63. [CrossRef]

73. Lemos, N.G.; e Braccini, A.D.L.; Abdelnoor, R.V.; de Oliveira, M.C.N.; Suenaga, K.; Yamanaka, N. Characterization of genes Rpp2, Rpp4, and Rpp5 for resistance to soybean rust. Euphytica 2011, 182, 53-64. [CrossRef]

74. Yu, N.; Kim, M.; King, Z.R.; Harris, D.K.; Buck, J.W.; Li, Z.; Diers, B.W. Fine mapping of the Asian soybean rust resistance gene Rpp2 from soybean PI 230970. Theor. Appl. Genet. 2015, 128, 387-396. [CrossRef]

75. Brogin, R.L. Mapeamento de genes de resistência à ferrugem e de QTLs envolvidos na resistência à septoriose em soja. Ph.D. Thesis, Universidade de São Paulo, São Paulo, Brazil, 2005. (In Portuguese)

76. Monteros, M.J.; Missaoui, A.M.; Phillips, D.V.; Walker, D.R.; Boerma, H.R. Mapping and confirmation of the 'Hyuuga' red-brown lesion resistance gene for Asian soybean rust. Crop Sci. 2007, 47, 829-834. [CrossRef]

77. Ray, J.D.; Smith, J.R.; Morel, W.; Bogado, N.; Walker, D.R. Genetic resistance to soybean rust in PI 567099A in at or near the Rpp3 locus. J. Crop Improv. 2011, 25, 219-231. [CrossRef]

78. Vuong, T.D.; Walker, D.R.; Nguyen, B.T.; Nguyen, T.T.; Dinh, H.X.; Hyten, D.L.; Cregan, P.B.; Sleper, D.A.; Lee, J.D.; Shannon, J.G.; et al. Molecular characterization of resistance to soybean rust (Phakopsora pachyrhizi Syd. \& Syd.) in soybean cultivar DT 2000 (PI 635999). PLoS ONE 2016, 11, e0164493.

79. Hartwig, E.E. Identification of a fourth major gene conferring resistance to soybean rust. Crop Sci. 1986, 26, 1135-1136. [CrossRef]

80. Meyer, J.D.; Silva, D.C.; Yang, C.; Pedley, K.F.; Zhang, C.; van de Mortel, M.; Hill, J.H.; Shoemaker, R.C.; Abdelnoor, R.V.; Whitham, S.A.; et al. Identification and analyses of candidate genes for Rpp4-mediated resistance to Asian soybean rust in soybean. Plant Physiol. 2009, 150, 295-307. [CrossRef] [PubMed]

81. Matsuo, É.; Sediyama, T.; Brommonschenkel, S.H.; Cruz, C.D. Inheritance and genetic mapping of resistance to Asian soybean rust in cultivar TMG 803. Crop Breed. Appl. Biotechnol. 2014, 14, 209-215. [CrossRef]

82. King, Z.R.; Harris, D.K.; Pedley, K.F.; Song, Q.; Wang, D.; Wen, Z.; Buck, J.W.; Li, Z.; Boerma, H.R. A novel Phakopsora pachyrhizi resistance allele (Rpp) contributed by PI 567068A. Theor. Appl. Genet. 2015, 129, 517-534. [CrossRef]

83. Liu, M.; Li, S.; Swaminathan, S.; Sahu, B.B.; Leandro, L.F.; Cardinal, A.J.; Bhattacharyya, M.K.; Song, Q.; Walker, D.R.; Cianzio, S.R. Identification of a soybean rust resistance gene in PI 567104B. Theor. Appl. Genet. 2016, 129, 863-877. [CrossRef] [PubMed]

84. Hovmoller, M.S.; Sorensen, C.K.; Walter, S.; Justesen, A.F. Diversity of Puccinia striiformis on cereals and grasses. Annu. Rev. Phytopathol. 2011, 49, 197-217. [CrossRef]

85. Yamaoka, Y. Recent outbreaks of rust diseases and the importance of basic biological research for controlling rusts. J. Gen. Plant Pathol. 2014, 80, 375-388. [CrossRef]

86. Twizeyimana, M.; Ojiambo, P.S.; Haudenshield, J.S.; Caetano-Anollés, G.; Pedley, K.F.; Bandyopadhyay, R.; Hartman, G.L. Genetic structure and diversity of Phakopsora pachyrhizi isolates from soybean. Plant Pathol. 2011, 60, 719-729. [CrossRef] 
87. Zhang, X.C.; Freire, M.C.M.; Le, M.H.; De Oliveira, L.O.; Pitkin, J.W.; Segers, G.; Concibido, V.C.; Baley, G.J.; Hartman, G.L.; Upchurch, G.; et al. Genetic diversity and origins of Phakopsora pachyrhizi isolates in the United States. Asian J. Plant Pathol. 2012, 6, 52-65.

88. Freire, M.C.M.; da Silva, M.R.; Zhang, X.; Almeida, Á.M.R.; Stacey, G.; de Oliveira, L.O. Nucleotide polymorphism in the $5.8 \mathrm{~S}$ nrDNA gene and internal transcribed spacers in Phakopsora pachyrhizi viewed from structural models. Fungal Genet. Biol. 2012, 49, 95-100. [CrossRef] [PubMed]

89. Jorge, V.R.; Silva, M.R.; Guillin, E.A.; Freire, M.C.M.; Schuster, I.; Almeida, A.M.R.; Oliveira, L.O. The origin and genetic diversity of the causal agent of Asian soybean rust, Phakopsora pachyrhizi, in South America. Plant Pathol. 2015, 64, 729-737. [CrossRef]

90. Yamanaka, N.; Silva, D.C.G.; Passianotto, A.L.L.; Nogueira, L.M.; Polizel, A.M.; Pereira, S.S.; Santos, J.V.M.; Brogin, R.L.; Arias, C.A.A.; Hoffmann-Campo, C.B.; et al. Identification of DNA markers and characterization of the genes for resistance against Asian soybean rust. In JIRCAS Working Report No. 58; Kudo, H., Suenaga, K., Soares, R.M., Toledo, A., Eds.; JIRCAS: Tsukuba, Japan, 2008; pp. 99-107.

91. Kato, M.; Yorinori, J.T. A study on a race composition of Phakopsora pachyrhizi in Brazil: A difficulty of race identification. In JIRCAS Working Report No. 58; Kudo, H., Suenaga, K., Soares, R.M., Toledo, A., Eds.; JIRCAS: Tsukuba, Japan, 2008; pp. 94-98.

92. Singh, B.B.; Thapliyal, P.N. Breeding for resistance to soybean rust in India. In Rust of Soybean- the Problem and Research Needs; Ford, R.E., Sinclair, J.B., Eds.; INTSOY Series No. 12; University of Illinois: Urbana, IL, USA, 1977.

93. Ribeiro, A.S.; Moreira, J.U.V.; Pierozzi, P.H.B.; Rachid, B.F.; de Toledo, J.F.F.; Arias, C.A.A.; Soares, R.M.; Godoy, C.V. Genetic control of Asian rust in soybean. Euphytica 2007, 157, 15-25. [CrossRef]

94. Miles, M.R.; Frederick, R.D.; Hartman, G.L. Evaluation of soybean germplasm for resistance to Phakopsora pachyrhizi. Plant Health Prog. 2006, 7, 33. [CrossRef]

95. Walker, D.R.; Boerma, H.R.; Phillips, D.V.; Schneider, R.W.; Buckley, J.B.; Shipe, E.R.; Mueller, J.D.; Weaver, D.B.; Sikora, E.J.; Moore, S.H.; et al. Evaluation of USDA soybean germplasm accessions for resistance to soybean rust in the southern United States. Crop Sci. 2011, 51, 678-693. [CrossRef]

96. Walker, D.R.; Harris, D.K.; King, Z.R.; Li, Z.; Phillips, D.V.; Buck, J.W.; Nelson, R.L.; Boerma, H.R. Soybean germplasm accession seedling reactions to soybean rust isolates from Georgia. Crop Sci. 2014, 54, 1433-1447. [CrossRef]

97. Miles, M.R.; Morel, W.; Ray, J.D.; Smith, J.R.; Frederick, R.D.; Hartman, G.L. Adult plant evaluation of soybean accessions for resistance to Phakopsora pachyrhizi in the field and greenhouse in Paraguay. Plant Dis. 2008, 92, 96-105. [CrossRef]

98. Li, S. Reaction of soybean rust-resistant lines identified in Paraguay to Mississippi isolates of Phakopsora pachyrhizi. Crop Sci. 2009, 49, 887-894. [CrossRef]

99. Whitham, S.A.; Qi, M.; Innes, R.W.; Ma, W.; Lopes-Caitar, V.; Hewezi, T. Molecular soybean-pathogen interactions. Annu. Rev. Phytopathol. 2016, 54, 443-468. [CrossRef]

100. Pedley, K.F.; Pandey, A.K.; Ruck, A.; Lincoln, L.M.; Whitham, S.A.; Graham, M.A. Rpp1 encodes a ULP1-NBS-LRR protein that controls immunity to Phakopsora pachyrhizi in soybean. Mol. Plant Microbe Interact. 2018, 32, 120-133. [CrossRef] [PubMed]

101. Liu, J.Z.; Graham, M.A.; Pedley, K.F.; Whitham, S.A. Gaining insight into soybean defense responses using functional genomics approaches. Brief Funct. Genomics 2015, 14, 283-290. [CrossRef] [PubMed]

102. Van de Mortel, M.; Recknor, J.C.; Graham, M.A.; Nettleton, D.; Dittman, J.D.; Nelson, R.T.; Godoy, C.V.; Abdelnoor, R.V.; Almeida, A.M.R.; Baum, T.J.; et al. Distinct biphasic mRNA changes in response to Asian soybean rust infection. Mol. Plant Microbe Interact. 2007, 20, 887-899. [CrossRef] [PubMed]

103. Schneider, K.T.; van de Mortel, M.; Bancroft, T.J.; Braun, E.; Nettleton, D.; Nelson, R.T.; Frederick, R.D.; Baum, T.J.; Graham, M.A.; Whitham, S.A. Biphasic gene expression changes elicited by Phakopsora pachyrhizi in soybean correlate with fungal penetration and haustoria formation. Plant Physiol. 2011, 157, 355-371. [CrossRef] [PubMed]

104. Pandey, A.K.; Yang, C.; Zhang, C.; Graham, M.A.; Horstman, H.D.; Lee, Y.; Zabotina, O.A.; Hill, J.H.; Pedley, K.F.; Whitham, S.A. Functional analysis of the Asian soybean rust resistance pathway mediated by Rpp2. Mol. Plant Microbe Interact. 2011, 24, 194-206. [CrossRef] [PubMed] 
105. Morales, A.M.A.P.; O’Rourke, J.A.; van de Mortel, M.; Scheider, K.T.; Bancroft, T.J.; Borém, A.; Nelson, R.T.; Nettleton, D.; Baum, T.J.; Shoemaker, R.C.; et al. Transcriptome analyses and virus induced gene silencing identify genes in the Rpp4-mediated Asian soybean rust resistance pathway. Funct. Plant Biol. 2013, 40, 1029-1047. [CrossRef]

106. Ishiga, Y.; Uppalapati, S.R.; Gill, U.S.; Huhman, D.; Tang, Y.; Mysore, K.S. Transcriptomic and metabolomic analyses identify a role for chlorophyll catabolism and phytoalexin during Medicago nonhost resistance against Asian soybean rust. Sci. Rep. 2015, 5, 13061. [CrossRef] [PubMed]

107. Hossain, M.Z.; Ishiga, Y.; Yamanaka, N.; Ogiso-Tanaka, E.; Yamaoka, Y. Soybean leaves transcriptomic data dissects the phenylpropanoid pathway genes as a defence response against Phakopsora pachyrhizi. Plant Physiol. Biochem. 2018, 132, 424-433. [CrossRef] [PubMed]

108. Li, Z.K.; Sanchez, A.; Angeles, E.; Singh, S.; Domingo, J.; Huang, N.; Khush, G.S. Are the dominant and recessive plant disease resistance genes similar? A case study of rice R genes and Xanthomonas oryzae pv. oryzae races. Genetics 2001, 159, 757-765.

109. Yamanaka, N.; Lemos, N.G.; Akamatsu, H.; Yamaoka, Y.; Silva, D.C.; Abdelnoor, R.V.; Soares, R.M.; Suenaga, K. Soybean breeding materials useful for resistance to soybean rust in Brazil. Jpn. Agric. Res. Q. 2011, 45, 385-395. [CrossRef]

110. Martins, J.A.S.; Juliatti, F.C. Genetic control of partial resistance to Asian soybean rust. Acta Sci. Agron. 2014, 36, 11-17. [CrossRef]

111. Burdon, J.J.; Barrett, L.G.; Rebetzke, G.; Thrall, P.H. Guiding deployment of resistance in cereals using evolutionary principles. Evol. Appl. 2014, 7, 609-624. [CrossRef] [PubMed]

112. Yorinori, J.T. Soybean germplasms with resistance and tolerance to Asian rust and screening methods. In JIRCAS Working Report No. 58: Facing the challenge of soybean rust in South America; Kudo, H., Suenaga, K., Soares, R.M., Toledo, A., Eds.; JIRCAS: Tsukuba, Japan, 2008; pp. 70-87.

113. Manwan, I.; Sama, S.; Rizvi, S.A. Use of varietal rotation in the management of rice tungro disease in Indonesia. Res. Dev. J. 1985, 7, 43-48.

114. Crill, P.; Ham, Y.S.; Beachell, H.M. The rice blast disease in Korea and its control with race prediction and gene rotation. Korean J. Breed. 1981, 13, 106-114.

115. Pedersen, W.L. Pyramiding major genes for resistance to maintain residual effects. Ann. Rev. Phytopathol. 1988, 26, 369-378. [CrossRef]

116. Yamanaka, N.; Lemos, N.G.; Uno, M.; Akamatsu, H.; Yamaoka, Y.; Abdelnoor, R.V.; Braccini, A.L.; Suenaga, K. Resistance to Asian soybean rust in soybean lines with the pyramided three Rpp genes. Crop Breed. Appl. Biotechnol. 2013, 13, 75-82. [CrossRef]

117. Maphosa, M.; Talwana, H.; Tukamuhabwa, P. Enhancing soybean rust resistance through Rpp2, Rpp3 and Rpp4 pairwise gene pyramiding. Afr. J. Agric. Res. 2012, 7, 4271-4277. [CrossRef]

118. Boutrot, F.; Zipfel, C. Function, discovery, and exploitation of plant pattern recognition receptors for broad-spectrum disease resistance. Annu. Rev. Phytopathol. 2017, 55, 257-286. [CrossRef] [PubMed]

119. Nuernberger, T.; Lipka, V. Non-host resistance in plants: New insights into an old phenomenon. Mol. Plant Pathol. 2005, 6, 335-345. [CrossRef] [PubMed]

120. Fonseca, J.P.; Mysore, K.S. Genes involved in nonhost disease resistance as a key to engineer durable resistance in crops. Plant Sci. 2019, 279, 108-116. [CrossRef] [PubMed]

121. Langenbach, C.; Campe, R.; Schaffrath, U.; Goellner, K.; Conrath, U. UDP-glucosyltransferase UGT84A2/ BRT1 is required for Arabidopsis nonhost resistance to the Asian soybean rust pathogen Phakopsora pachyrhizi. New Phytol. 2013, 198, 536-545. [CrossRef] [PubMed]

122. Langenbach, C.; Schultheiss, H.; Rosendahl, M.; Tresch, N.; Conrath, U.; Goellner, K. Interspecies gene transfer provides soybean resistance to a fungal pathogen. Plant Biotech. J. 2016, 14, 699-708. [CrossRef] [PubMed]

123. Kawashima, C.G.; Guimarães, G.A.; Nogueira, S.R.; MacLean, D.; Cook, D.R.; Steuernagel, B.; Baek, J.; Bouyioukos, C.; do Va Melo, B.; Tristão, G.; et al. A pigeonpea gene confers resistance to Asian soybean rust in soybean. Nat. Biotechnol. 2016, 34, 661-665. [CrossRef] [PubMed]

124. Johnson, R. Letter to the editor: The concept of durable resistance. Phytopathology 1979, 69, $198-199$. [CrossRef]

125. Flor, H.H. Inheritance of pathogenicity in Melampsora lini. Phytopathology 1942, 32, 653-669. 
126. Hartman, G.L.; Wang, T.C.; Hymowitz, T. Sources of resistance to soybean rust in perennial Glycine species. Plant Dis. 1992, 76, 396-399. [CrossRef]

127. Sherman-Broyles, S.; Bombarely, A.; Powell, A.F.; Doyle, J.L.; Egan, A.N.; Coate, J.E.; Doyle, J.J. The wild side of a major crop: Soybean's perennial cousins from Down Under. Am. J. Bot. 2014, 101, 1651-1665. [CrossRef] [PubMed]

128. Mammadov, J.; Buyyarapu, R.; Guttikonda, S.K.; Parliament, K.; Abdurakhmonov, I.; Kumpatla, S.P. Wild relatives of maize, rice, cotton, and soybean: Treasure troves for tolerance to biotic and abiotic stresses. Front. Plant Sci. 2018, 9, 886. [CrossRef]

129. REX Consortium. Combining selective pressures to enhance the durability of disease resistance genes. Front. Plant Sci. 2016, 7, 1916.

130. Watkinson-Powell, B.; Gilligan, C.A.; Cunniffe, N.J. When does spatial diversification usefully maximise the durability of crop disease resistance? BioRxiv 2019, 540013. [CrossRef]

131. Mendgen, K.; Wirsel, S.G.R.; Jux, A.; Hoffmann, J.; Boland, W. Volatiles modulate the development of plant pathogenic rust fungi. Planta 2006, 224, 1353-1361. [CrossRef] [PubMed]

132. Da Cruz, M.F.A.; Rodrigues, F.A.; Polanco, L.R.; da Silva Curvelo, C.R.; Nascimento, K.J.T.; Moreira, M.A.; Barros, E.G. Inducers of resistance and silicon on the activity of defense enzymes in the soybean-Phakopsora pachyrhizi interaction. Bragantia 2013, 72, 162-172. [CrossRef]

133. Da Silva, A.C.; de Souza, P.E.; Amaral, D.C.; Zeviani, W.M.; Pinto, J.E.B.P. Essential oils from Hyptis marrubioides, Aloysia gratissima and Cordia verbenacea reduce the progress of Asian soybean rust. Acta Sci. Agron. 2014, 36, 159-166. [CrossRef]

134. Dorighello, D.V.; Bettiol, W.; Maia, N.B.; de Campos Leite, R.M.V.B. Controlling Asian soybean rust (Phakopsora pachyrhizi) with Bacillus spp. and coffee oil. Crop Prot. 2015, 67, 59-65. [CrossRef]

135. Mehta, Y.R.; Marangoni, M.S.; Matos, J.N.; Mandarino, J.M.G.; Galbieri, R. Systemic acquired resistance of soybean to soybean rust induced by shale water. Am. J. Plant Sci. 2015, 6, 2249-2256. [CrossRef]

136. Srivastava, P.; George, S.; Marois, J.J.; Wright, D.L.; Walker, D.R. Saccharin-induced systemic acquired resistance against rust (Phakopsora pachyrhizi) infection in soybean: Effects on growth and development. Crop Prot. 2011, 30, 726-732. [CrossRef]

137. Liang, Y.; Nikolic, M.; Bélanger, R.; Gong, H.; Song, A. Silicon in Agriculture: From Theory to Practice; Springer: Dordrecht, The Netherlands, 2015.

138. Rodrigues, F.A.; Duarte, H.S.S.; Domiciano, G.P.; Souza, C.A.; Korndorfer, G.H.; Zambolim, L. Foliar application of potassium silicate reduces the intensity of soybean rust. Australas. Plant Pathol. 2009, 38, 366-372. [CrossRef]

139. Lemes, E.M.; Mackowiak, C.L.; Blount, A.; Marois, J.J.; Wright, D.L.; Coelho, L.; Datnoff, L.E. Effects of silicon applications on soybean rust development under greenhouse and field conditions. Plant Dis. 2011, 95, 317-324. [CrossRef]

140. Arsenault-Labrecque, G.; Menzies, J.G.; Belanger, R.R. Effect of silicon absorption on soybean resistance to Phakopsora pachyrhizi in different cultivars. Plant Dis. 2012, 96, 37-42. [CrossRef]

141. Kumar, S.; Jha, D.K. Trichotheciumroseum: A potential agent for the biological control of soybean rust. Indian Phytopathol. 2002, 55, 232-234.

142. Ward, N.A.; Robertson, C.L.; Chanda, A.K.; Schneider, R.W. Effects of Simplicillium lanosoniveum on Phakopsora pachyrhizi, the soybean rust pathogen, and its use as a biological control agent. Phytopathology 2012, 102, 749-760. [CrossRef] [PubMed]

(C) 2019 by the authors. Licensee MDPI, Basel, Switzerland. This article is an open access article distributed under the terms and conditions of the Creative Commons Attribution (CC BY) license (http://creativecommons.org/licenses/by/4.0/). 